\title{
The effects of synoptical weather pattern and complex terrain on the formation of aerosol events in the Greater Taipei area
}

\author{
Ming-Tung Chuang ${ }^{a}$, Pen-Chi Chiang ${ }^{b}$, Chang-Chuan Chan ${ }^{c}$, Chu-Fang Wang ${ }^{d}$, \\ E-E Chang ${ }^{e}$, Chung-Te Lee ${ }^{a, *}$ \\ ${ }^{a}$ Graduate Institute of Environmental Engineering, National Central University, Jhongli, 32001, Taiwan \\ ${ }^{\mathrm{b}}$ Graduate Institute of Environmental Engineering, National Taiwan University, Taipei, 10617 Taiwan \\ ${ }^{\mathrm{C}}$ Institute of Occupational Medicine and Industrial Hygiene, National Taiwan University, Taipei, 100 Taiwan \\ ${ }^{d}$ Institute of Nuclear Engineering and Science, National Tsing-Hua University, Hsinchu, 30013 Taiwan \\ ${ }^{\mathrm{e}}$ Department of Biochemistry, School of Medicine, Taipei Medical University, Taipei, 110 Taiwan
}

\section{A R T I C L E I N F O}

Article history:

Received 28 April 2007

Received in revised form

26 January 2008

Accepted 30 January 2008

Keywords:

Atmospheric aerosols

Aerosol properties

Aerosol event

Synoptical weather pattern

Complex terrain

\begin{abstract}
A B S T R A C T
The aerosol in the Taipei basin is difficult to transport outward under specific weather patterns owing to complex terrain blocking. In this study, seven weather patterns are identified from synoptic weather maps for aerosol events, which occurred from March 2002 to February 2005. Among the identified weather patterns, High Pressure Peripheral Circulation (HPPC), Warm area Ahead of a cold Front (WAF), TYPhoon (TYP), Pacific High Pressure system stretching westerly (PHP), Weak High Pressure system (WHP), and Weak Southern Wind (WSW) are related to terrain blocking. The remaining pattern is High Pressure system Pushing (HPP). The classification of the pollution origin of the air masses shows that $15 \%$ of event days were contributed by long-range transport (LRT), $20 \%$ by local pollution (LP), and 65\% by LRT/LP mix. Terrain blocking causes aerosol accumulation from high atmospheric stability and weak winds occurring under HPPC, TYP, and PHP weather patterns when the Taipei basin is situated on the lee side of the Snow Mountains Chain (SMC). Terrain blocking also occurs when the Taipei basin is situated on the upwind of SMC and Mt. Da-Twen under WAF and WSW patterns.

To study the variation of aerosol properties under the mixed influence of terrain and pollution origin, we conducted a field observation simultaneously at the urban, suburban, and background sites in the Greater Taipei area from April 14 to 23, 2004. Terrain blocking plays an important role in aerosol accumulation in the stagnant environment when the Taipei basin is on the lee side of SMC. On the other hand, the $\mathrm{PM}_{2.5}$ sulfate level is stable with a fraction of $30 \%$ in $\mathrm{PM}_{2.5}$ during the observation period at the urban (25\%-33\%) and background (25\%-41\%) sites. It indicates that background $\mathrm{PM}_{2.5}$ sulfate is high on the West Pacific in winter.
\end{abstract}

(c) 2008 Elsevier B.V. All rights reserved.

\section{Introduction}

In the last decade, a number of studies have focused on the causes of long-range transport (LRT) and local air pollution (LP)
(Lu and Turco, 1995; Sun and Wexler, 1998; Venegas and Mazzeo, 1999; Jiang et al., 2000; Oettl et al., 2001; Jazcilevich et al., 2003, 2005; Chen et al., 2004; Cousin et al., 2005; Schmitz, 2005; Lam et al., 2005). Several studies also investigated the

\footnotetext{
* Corresponding author. Graduate Institute of Environmental Engineering, National Central University No.300, Jhongda Rd., Jhongli City, Taoyuan County 32001, Taiwan. Tel.: +886 34227151x34657; fax: +886 34221602.

E-mail address: ctlee@cc.ncu.edu.tw (C.-T. Lee).
} 


\title{
Acronyms and abbreviations
}

\author{
Aerosol and its compositions \\ EC Elemental Carbon \\ OC Organic Carbon \\ OM Organic Matter \\ $\mathrm{PM}_{2.5} \quad$ Particulate matter with an aerodynamic diameter equal to or smaller than $2.5 \mu \mathrm{m}$ \\ $\mathrm{PM}_{10} \quad$ Particulate matter with an aerodynamic diameter equal to or smaller than $10 \mu \mathrm{m}$
}

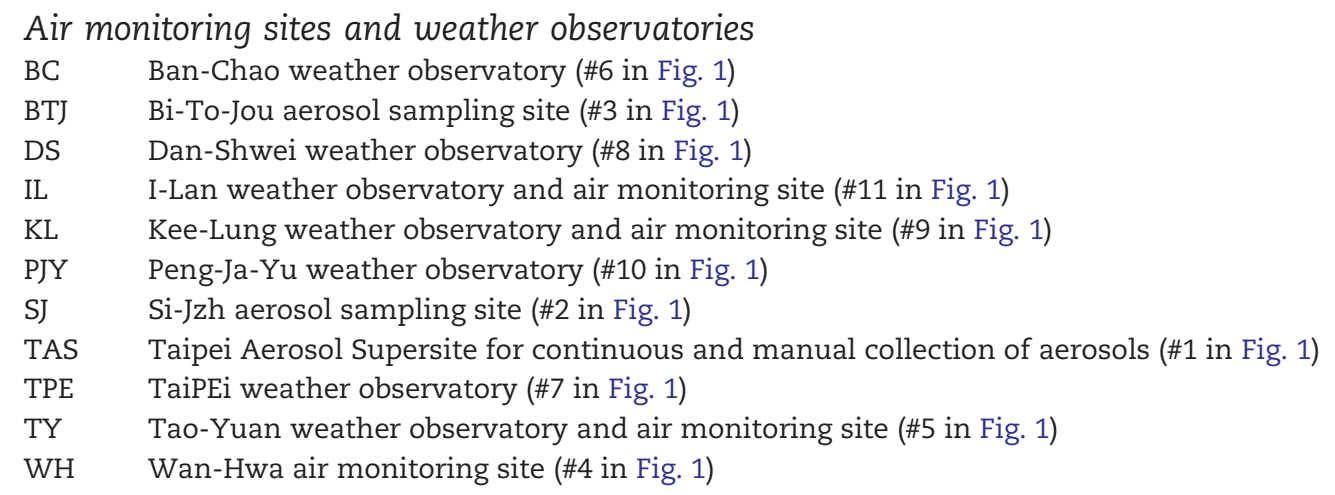

\section{Geographical locations \\ CMR Central Mountains Range \\ SMC Snow Mountains Chain}

\author{
Oganizations \\ DBAR Data Bank of Atmospheric Research \\ JMA Japan Meteorology Agency \\ TCWB Taiwan Central Weather Bureau \\ TEPA Taiwan Environmental Protection Administration
}

\author{
Weather patterns \\ HPP High Pressure Pushing \\ HPPC High Pressure Peripheral Circulation \\ PHP Pacific High Pressure system stretching westerly \\ TYP TYPhoon \\ WAF Warm area Ahead of a cold Front \\ WHP Weak High Pressure system \\ WSW Weak Southern Wind
}

Others

CCSEM Computer Controlled Scanning Electron Microscope

LP Local Pollution

LRT Long-Range Transport

LRT/LP a mix of LRT and LP

ROS Reactive Oxygen Species

TOR Thermal Optical Reflectance for aerosol carbon analysis

health effects of fine particles (Oberdörster et al., 1995, 2002; Seaton et al., 1995; Donaldson et al., 1998; Batalha et al., 2002; Utell, 2006). Thus, it is worthwhile to study how $\mathrm{PM}_{2.5}$ events (high particulate level with aerodynamic diameter of ambient aerosols equal to or smaller than $2.5 \mu \mathrm{m}$ ) are formed. Only through a thorough investigation of $\mathrm{PM}_{2.5}$ events can effective control measures be put forward by policy makers (Kleeman and Cass, 1999). 
As atmospheric aerosols are not uniform but are rather varied in temporal and spatial scales, a study of the local terrain as associated with weather patterns and pollutant transport is important. In the past, there have been many studies which focused on the effects of air flow passing over mountains. These studies can be traced back to as early as the 1970s; for example, for stable stratified flow passing over three dimensional terrains, Brighton (1977) and Hunt and Snyder (1980) conducted model experiments; Smith (1979) and Smith (1980) proposed theoretical algorithms; while Smolarkiewicz et al. (1988), Smolarkiewicz and Rotunno (1989), Sun et al. (1991), Lin et al. (1992), and Archer and Jacobson (2005) worked on numerical simulations. Three features can be identified from the studies of stable stratified flow passing over a complex terrain. First, a supercritical air stream (Froude number $>1.0$ ) can climb over mountains and form downwash wind on the lee side. In contrast, subcritical flow (Froude number <1.0) can only skirt around mountains for lack of momentum. Second, the upwind side and lee side are individually situated in relatively high pressure and low pressure zones, thus resulting in the formation of vortices on the lee side. Third, several stagnant points may appear both on the upwind and lee sides of the mountains. Studies on the combination of synoptical weather conditions and complex terrain leading to pollution in an area are available. For example, Dosio et al. (2001) utilized a meteorological model to elucidate the occurrence of high ozone level in the deep Italian Alpine valley caused by a decoupling of local circulation from the synoptic air flow under an anticyclone weather pattern. Almbauer et al. (2000) and subsequently Oettl et al. (2001) explained the cause of a weak southerly wind of less than $2 \mathrm{~m}$ $\mathrm{s}^{-1}$ that developed in the southern part of Graz, a city located in a basin southeast of the main ridge of the Alps in winter. This was found to be due to the convergence of southerly and prevailing northwesterly winds over the complex terrain. In addition, Jazcilevich et al. (2005) attributed the air pollution in the valley of Mexico from locally induced surface air confluence over complex terrain under a high-pressure system. On the other hand, several studies focused on the relationship between air pollution and synoptic weather patterns. For instance, Kassomenos et al. (1998) classified eleven distinct mesoscale patterns by analyzing meteorological sources gathered within a 13-year period. They found that severe and bad air quality conditions were highly related to southerly sea breeze and calm wind. Further, Kassomenos et al. (2001) investigated the short-term effect of eight synoptic weather patterns and eleven mesoscale weather types existing in Athens, Greece. Dayan and Lamb (2003) analyzed the daily precipitation chemistry for nine consecutive summers at central Pennsylvania, U.S.A. They found that a very great difference in acidity and ion concentration of rain water existed among seven storm types. Rainham et al. (2005) statistically correlated air pollution and human mortality according to seven air mass categories classified by Sheridan (2002). Turnbull and Harrison (2000) found that secondary nitrate and sulfate were related more to meteorological conditions such as different air masses in different seasons, and less to location in the UK.

There are over 6 million people living in the Greater Taipei area. Its population density reaches more than 30,000 people per square kilometer, and it ranks almost at the top among modern cities worldwide. The Greater Taipei area is under the authority of three local governments, namely Taipei City, Taipei County, and Kee-Lung City. An annual average of 120 million US dollars for air pollution control has been continuously put into this area by the governments for the past few years (TEPA, 2004, 2005). However, $\mathrm{PM}_{2.5}$ levels have not been reduced since 2002. In the past, only a few studies dealt with the ambient aerosol problem in Taipei. For example, Chen et al. (1999) conducted a field observation from October 1996 to June 1997. Their results showed that the average $\mathrm{PM}_{10}$ and $\mathrm{PM}_{2.5}$ mass concentrations were 42 and $23 \mu \mathrm{gm}^{-3}$, respectively, and the $\mathrm{PM}_{2.5} / \mathrm{PM}_{10}$ ratio was about $54-59 \%$. This gives a snapshot of the Taipei aerosol situation in the early days. A source apportionment of the analyzed elemental content of $\mathrm{PM}_{2.5}$ with Computer Controlled Scanning Electron Microscope (CCSEM) technique revealed that $73.3 \%$ of the analyed 24,579 Taipei particles could be attributed to vehicle-related activities; $12.4 \%$ to resuspended soil or dust; and the rest to industrial activities, secondary reactions, and sea spray aerosols (Chen et al., 2001). Hung and Wang (2001) analyzed the concentration of reactive oxygen species (ROS) in various particle size fractions for Taipei aerosols. They suggested that for the same particle mass concentration, smaller particles in ambient aerosols had higher ROS components, which might have a greater potential to cause damage to pulmonary cells. Chen et al. (2003) analyzed the hygroscopic characteristics of atmospheric aerosol, and concluded that $\left(\mathrm{NH}_{4}\right)_{2} \mathrm{SO}_{4}$ was the most abundant ambient aerosol in Taipei.

Even though there have been several studies related to ambient aerosol in Taipei, these studies conducted observations only over a selective time interval and were not able to record a severe aerosol event. Lee et al. (2006) mentioned that after the period of the Asian yellow-dust events, the $\mathrm{PM}_{2.5}$ level in Taipei often increased dramatically under high-pressure peripheral circulation weather pattern. Therefore, in this study, we classify synoptical weather patterns associated with aerosol events from March 2002 to February 2005. We will also demonstrate the coupling of a specific weather pattern with terrain effect in increasing the $\mathrm{PM}_{2.5}$ level in Taipei. Specifically, a high $\mathrm{PM}_{2.5}$ level observed in a stagnant environment owing to the blocking of mountains when Taipei is on the lee side of the prevailing wind will be elaborated. In addition, we will also report aerosol field observation and analyze the cause of the high $\mathrm{PM}_{2.5}$ level during the observation period.

\section{Study area and aerosol observation methods}

\subsection{Study area}

Fig. 1 shows a geographic illustration of Taiwan and the Greater Taipei area. The Central Mountain Range (CMR) is oriented at the north-northeast and south-southwest direction, and occupies nearly $70 \%$ of the area of Taiwan Island. The Greater Taipei area is located in the northern part of Taiwan. Meanwhile, the Taipei basin is surrounded by the Snow Mountains Chain (SMC) on the east and south sides, Mt. DaTwen on the north side, and Lin-Kou plateau on the west side. The Lin-Kou plateau is about 100 to $200 \mathrm{~m}$ in height. The summit of Mt. Da-Twen reaches about $1000 \mathrm{~m}$. SMC is part of CMR and spans up to $200 \mathrm{~m}$ on the north edge, ascending 


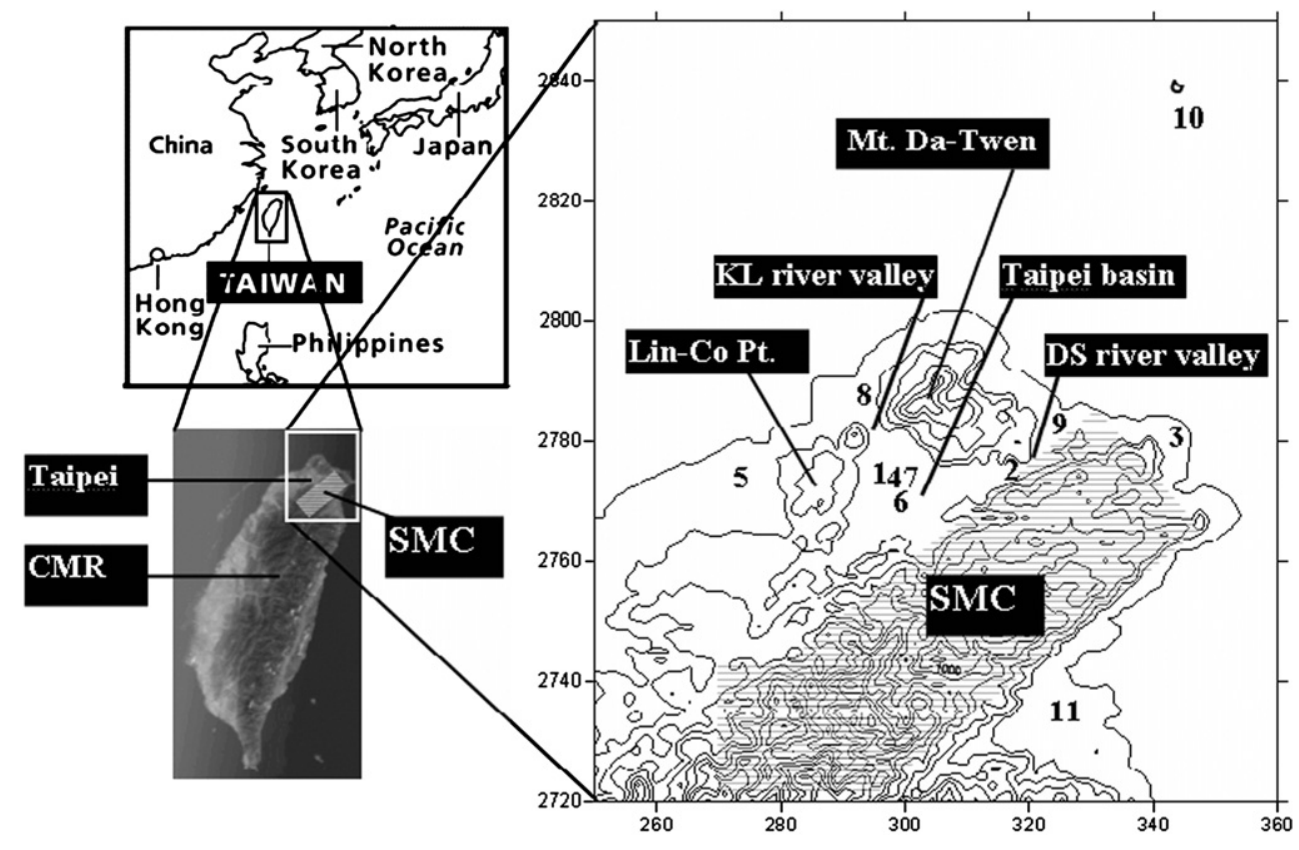

Fig. 1-Geographical location of the air quality monitoring sites (1: TAS, Taipei aerosol supersite; 2: SJ station; 3: BTJ station; 4: WH station; 5: TY station), weather observatories (6: BC station; 7: TPE station; 8: DS station; 9: KL station; 10: PJY station; 11: IL station), and the surrounding mountains (north of the Taipei basin: Mt. Da-Twen; east and south of the Taipei basin: Snow Mountain Chain (SMC, grey area on the map); west of the Taipei basin: Lin-Co plateau). Two river vallies located in the northeast and northwest orientations of the Taipei basin are called Dan-Shui (DS) river valley and Kee-Lung (KL) river valley, respectively. The copyright of lower left figure belongs to CSRSR (Center for Space and Remote Sensing Research, National Central University http://www.csrsr.ncu.edu.tw/).

gradually to $3000 \mathrm{~m}$ in central Taiwan (see Fig. 1). The DanShui and Kee-Lung river valleys are the two routes to the northwest and the northeast open sea, respectively.

\subsection{Aerosol observation sites}

With the prediction of the $\mathrm{PM}_{2.5}$ event from synoptic weather pattern, we held a field study from April 14 to 23, 2004. As mentioned above, SMC may block the prevailing southeast air stream when the prevailing wind does not have enough momentum to climb over SMC. Under the circumstances, the air current would possibly skirt the north edge of SMC and then reach the Taipei basin through Kee-Lung Valley. Thus, we choose BTJ (site \#3), SJ (site \#2), and TAS (site \#1) as our sampling sites along the presumed path of the air currents, as shown in Fig. 1. Furthermore, the TAS, SJ, and the BTJ sites can be considered as urban, suburban, and background sites, respectively. The sampling time was $12 \mathrm{~h}$. One period began from 08:00 to 20:00 (local time and thereafter), and the other was from 20:00 to 08:00 the next day. The sampling operation was executed simultaneously at all three sites. Besides the TAS site, the WH site (site \#4), which continuously monitors $\mathrm{PM}_{2.5}$ concentration in the Taipei basin, was used as a reference site to ensure that a high $\mathrm{PM}_{2.5}$ concentration event occurred in the Taipei basin during aerosol collection. The TY site (site \#5) was located southwest of the TAS site, and was used to observe if a southwest air stream transports aerosol around the west coastal cities northeastward to Taipei. Specifically, the WH and TY sites belong to the Taiwan Environmental Protection Administration (TEPA).

\subsection{Meteorology observation sites}

The BC (\#6 in Fig. 1) site is the only upper-air sounding site in the Greater Taipei area. The TPE (\#7) site stands for the surface meteorological site in the Taipei basin. The DS (\#8) and KL (\#9) sites are located at the outlet of Dan-Shui and Kee-Lung River Valleys. The PJY (\#10) site can be considered as a background site although the observed wind field may still be deflected by SMC. The above five sites belong to the Taiwan Central Weather Bureau (TCWB, http://www.cwb.gov.tw/). The IL (\#11) site is located east of SMC, and the wind field there is apt to be influenced by SMC. However, we think the pressure measurements of the IL site, which belongs to TEPA, are useful in this study.

\subsection{Aerosol collection and filter weighing}

At each aerosol sampling site, we used two Thermo Andersen Series $241 \mathrm{PM}_{10} / \mathrm{PM}_{2.5}$ Dichotomous Samplers (Thermo Andersen Instruments Inc., Smyrna, GA, USA) to collect $\mathrm{PM}_{10-2.5}$ and $\mathrm{PM}_{2.5}$. One sampler was installed with Teflon-membrane filters (37 mm, Teflo ${ }^{\text {TM }}$ W/Ring, Gelman Science, USA), and the other was loaded with quartz-fiber filters $(37 \mathrm{~mm}, 2500$ QAT-UP, Pallflex, Purtram, Conn, USA). Moreover, we used R\&P TEOM Model 1400a Ambient Particulate Monitor (Rupprecht \& Patashinick Co., Inc., Albany, NY, USA) to acquire continuous $\mathrm{PM}_{2.5}$ concentration at the TAS and BTJ sites.

The collected Teflon ${ }^{\circledR}$ filter was stored in a temperatureand humidity-controlled room $\left(25^{\circ} \mathrm{C}, 30 \pm 5 \% \mathrm{RH}\right)$ for $72 \mathrm{~h}$ before sampling and weighing. Every filter was weighed three 
times by a Mettler MX5 Microbalance (Mettler Toledo Co. Inc., Greifensee, Switzerland) with the sensitivity at $\pm 1 \mu \mathrm{g}$. Additional weighing was conducted when the difference between readings was greater than $\pm 3 \mu \mathrm{g}$. Aerosol mass concentration was calculated by dividing weighed mass by the actual air volume drawn through the sampler.

\subsection{Aerosol water-soluble inorganic ions and aerosol carbon content}

After weighing, the collected filter was ultrasonically extracted for $90 \mathrm{~min}$ in $10 \mathrm{ml}$ de-ionized distilled water (conductivity $>0.05 \mu \mathrm{mho} \mathrm{cm}^{-1}$ ) mixed with $200 \mu \mathrm{l}$ methanol, which was subsequently filtered through a Teflon ${ }^{\circledR}$ syringe filter with a $0.45 \mu \mathrm{m}$ pore size (Millipore Corp., Billerica, MA, USA). This filtrate was injected into an ion chromatograph (DX-120, Dionex Co., Inc., Sunnyvale, CA, USA) to measure the concentration of water-soluble inorganic ions. Aerosol carbonaceous content was analyzed using a DRI Model 2001A OC/EC Carbon Analyzer (Atmoslytic Inc., Calabasas, CA, USA), and Thermal Optical Reflectance (TOR) was employed to monitor organic carbon (OC) to elemental carbon (EC) conversion (Chow et al., 1993; Watson et al., 2005). The operating principle of this carbon analyzer is based on the preferential oxidation of OC and EC at different temperatures. The split of OC and EC is based on the fact that OC can be volatilized from the sample punch in a helium atmosphere at low temperatures, while EC is not oxidized and will be removed at higher temperatures. The analytical protocol was thus programmed to increase oven temperature gradually from room temperature to $120,250,450$, $550,700{ }^{\circ} \mathrm{C}$, and finally reaching $800{ }^{\circ} \mathrm{C}$. The reflectance of a laser beam from the surface of the analyzed filter was used to determine the pyrolyzed OC caused by the incomplete combustion in pure helium during OC analysis. Depending on the elution time of the corresponding temperature, OC is defined as the carbon that evolved from the filter punch in a helium atmosphere at $120,250,450$, and $550{ }^{\circ} \mathrm{C}$ plus the pyrolyzed OC; while EC is the carbon that evolved in $98 \%$ helium $/ 2 \%$ oxygen atmosphere at 550,700 , and $800{ }^{\circ} \mathrm{C}$ minus pyrolyzed OC. Pyrolyzed carbon is defined as the carbon that evolved between the moment when oxygen is introduced into the helium atmosphere at $550{ }^{\circ} \mathrm{C}$ and the moment when the surface reflectance of the filter punch returns to its initial value at the start of the analysis. The detection limit of aerosol EC and OC using the TOR method are 0.02 and $0.24 \mu \mathrm{g} \mathrm{m}^{-3}$, respectively. Replicate measurements for blank filters show that the precision of EC and OC analyses are 0.01 and $0.16 \mu \mathrm{g} \mathrm{m}^{-3}$, respectively.

\section{Results and discussion}

\section{1. $\mathrm{PM}_{2.5}$ events and weather patterns}

In this study, we define an 'event day' as at least one hour when the $\mathrm{PM}_{2.5}$ average concentration monitored at the TAS site exceeds $65 \mu \mathrm{g} \mathrm{m}^{-3}$ in one day. The installed instruments and operation of the TAS site are described in detail in the work of Lee et al. (2006). After identifying the event days, we made an overview of the daily surface weather map produced by TCWB and the Japan Meteorology Agency (JMA, http:// www.jma.go.jp/jp/g3/). According to the synoptic and mesoscale system that influenced Taiwan, we classified $\mathrm{PM}_{2.5}$ events into seven synoptic weather patterns. Fig. 2 shows the typical surface weather maps of these event weather patterns, which are characteristically described as follows.

Basically, during the cool season (autumn, winter, and spring), the occurrence of high $\mathrm{PM}_{2.5}$ concentration events is strongly related to the movement and location of the Asian continental high-pressure systems. When the Asian continental high-pressure system moves from China to the West Pacific, its peripheral circulation blows clockwise so as to give a southeast wind around Taiwan. At this moment, the Taipei basin is on the lee side of SMC. Terrain blocking decreases wind speed, and the lee side subsidence increases atmospheric stability. Pollutants accumulated under this weather pattern are defined as HPPC pattern (see Fig. 2(a)). The local characteristics of this weather pattern are weak winds in the Taipei basin, relatively high-pressure upwind of SMC to the low pressure in the downwind Taipei basin, and thus a vertically stable atmosphere above the Taipei basin. As mentioned by Cheng (2001), the ozone level increases in central Taiwan under a specific weather pattern, which is similar to HPPC. Although both cases are caused by terrain blocking, the difference is that the prevailing wind in the work of Cheng (2001) is east wind, while it is southeast wind in this study. The reason for this is that SMC is northeast to southwest-oriented, and is a few hundred meters high on the east side of the Taipei basin. Only the southeast wind, which is orthogonal to the orientation of SMC, can intensify the effect of terrain blocking. Meanwhile, CMR is about $3000 \mathrm{~m}$ high in the east of central Taiwan. Terrain blocking is only effective under a wind direction from the east-northeast to the east in central Taiwan. Depending on the location of the highpressure center in the Pacific Ocean, the prevailing wind under HPPC may differ from the northeast to the southeast. It was found that when the high-pressure ridge of the Asian continental anticyclone stretches into the South Pacific Ocean, or the center of air mass is located south of $30^{\circ} \mathrm{N}$, the peripheral circulation of the high-pressure system circulates clockwise and goes southeast, prevailing around north Taiwan. However, if the high-pressure center is located north of $30^{\circ} \mathrm{N}$, the prevailing wind would be a northeast wind in the Taipei basin, and SMC cannot play its terrain blocking role, which forms $\mathrm{PM}_{2.5}$ events.

When the leading edge of the high-pressure air mass, i.e. the cold front or stagnant front, gets very near Taiwan, Taiwan is located at the warm area ahead of the front. At this moment, the prevailing wind around Taiwan is a weak south or southwest wind. The south or southwest air stream flowing through west coastal cities may bring industrial and urban pollutants, which would accumulate in the Taipei basin as a result of Mt. DaTwen's blocking at the north side and SMC at the east side. This weather pattern is defined as WAF pattern (see Fig. 2(b)). If the leading edge of Asian continental high-pressure systems moves fast from China to Taiwan, $\mathrm{PM}_{2.5}$ events will occur accompanied by a prevailing strong northeast wind, which is observed at all sites in the Greater Taipei area. As this weather system moves over China coastal provinces, it carries pollutants southward. $\mathrm{PM}_{2.5}$ concentrations are aggravated when there 
a

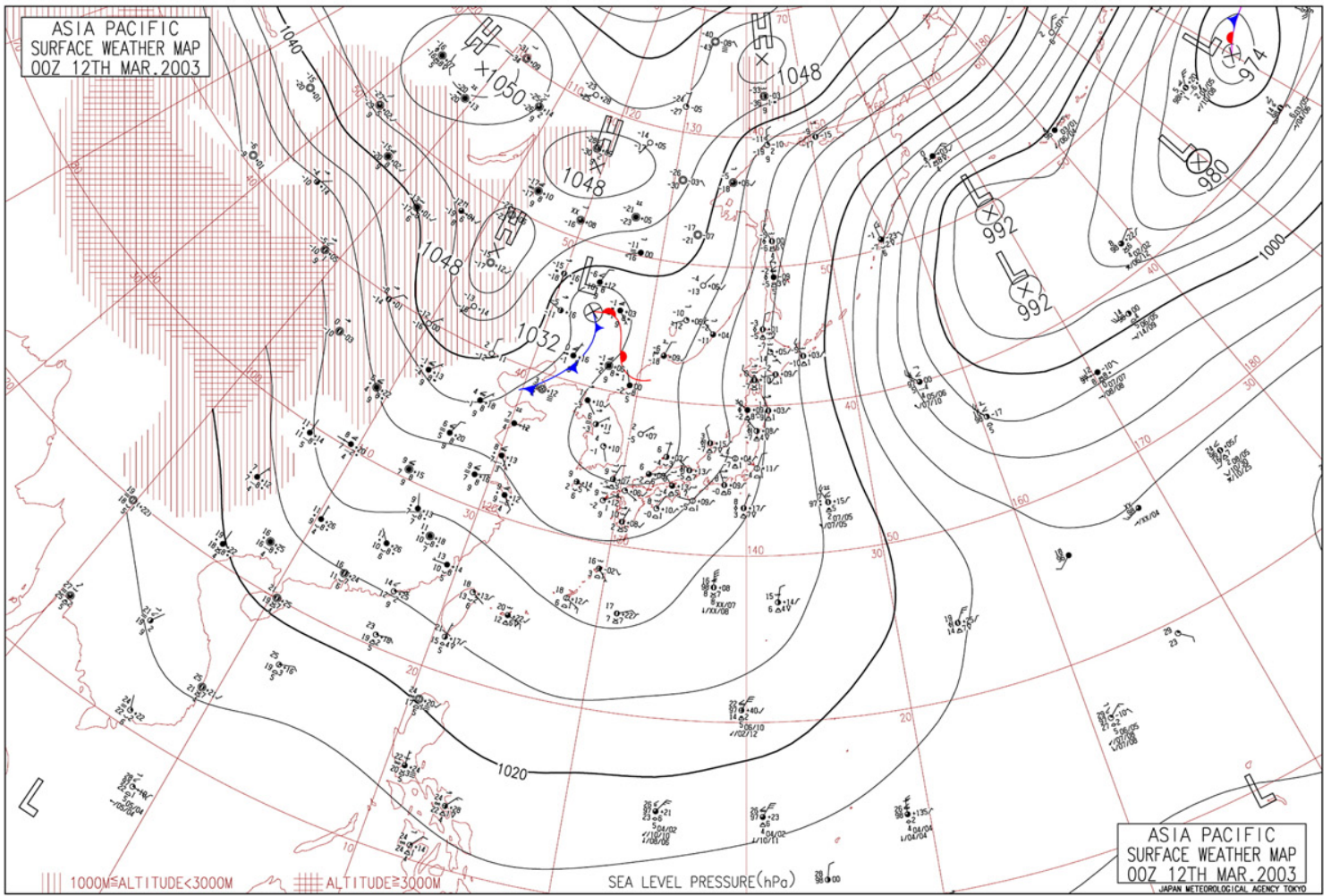

b

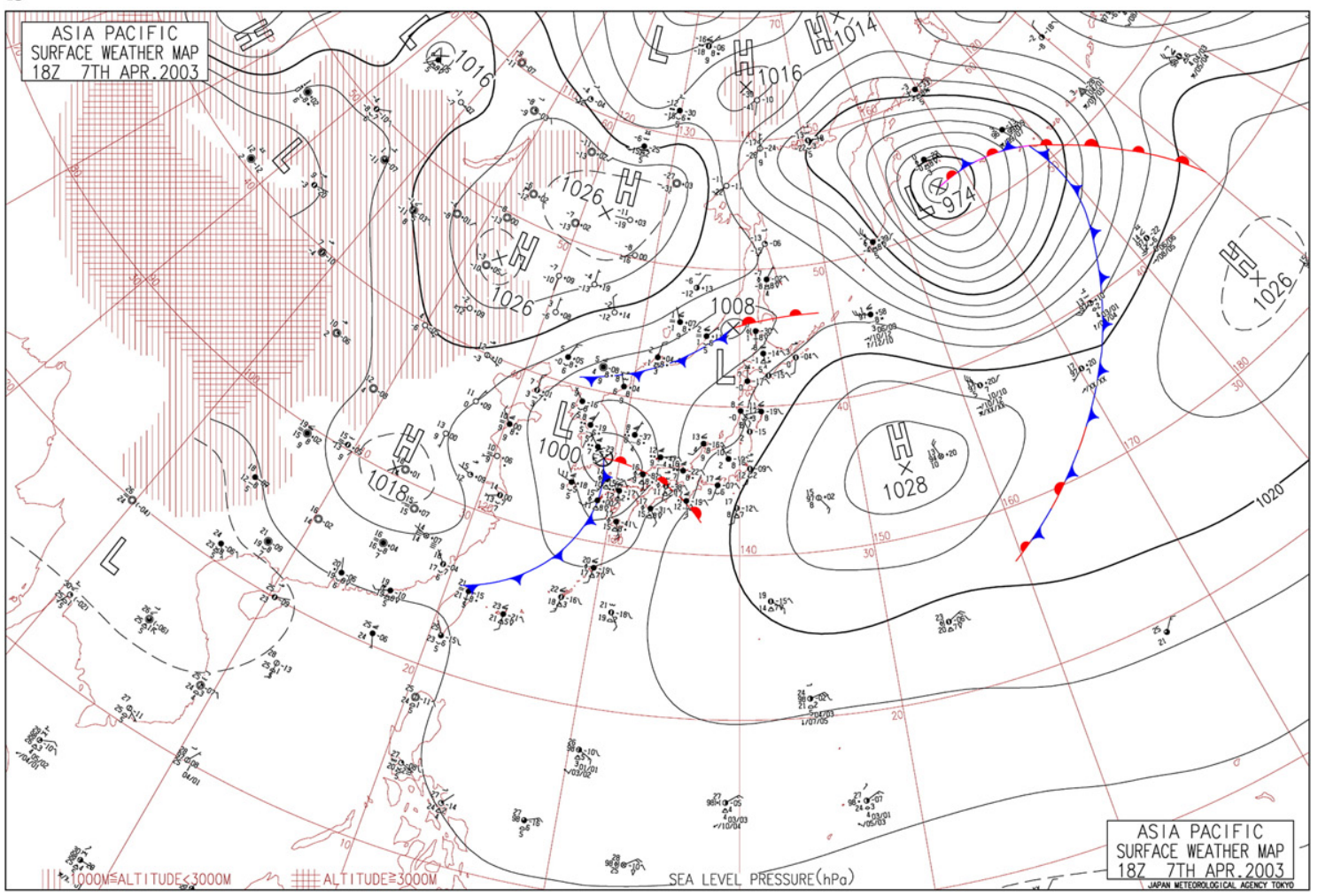

Fig. 2-Typical surface weather maps for the weather patterns classified in this study. All maps were promulgated by Taiwan Central Weather Bureau (http://www.jma.go.jp/jp/g3/). 


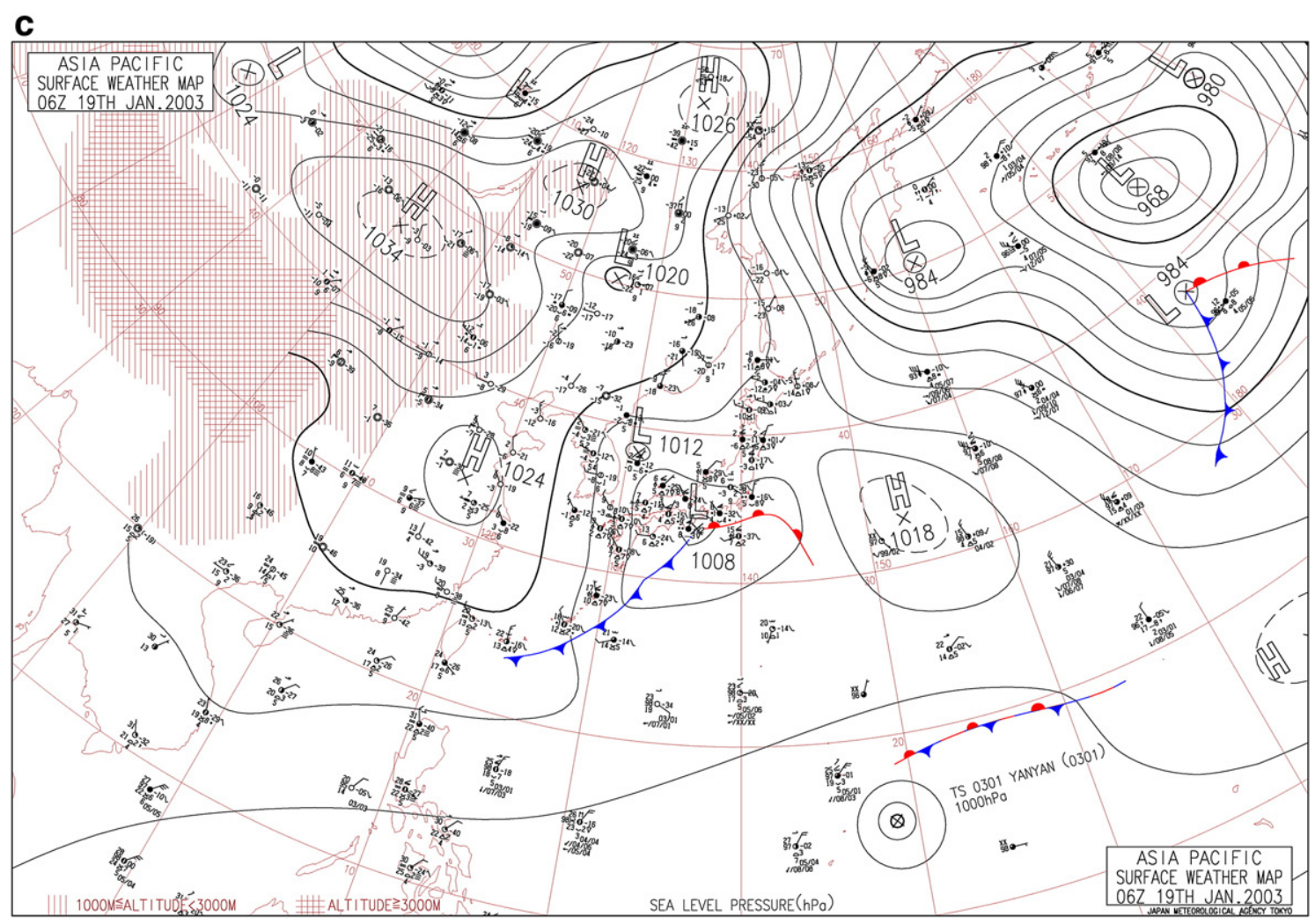

\section{d}

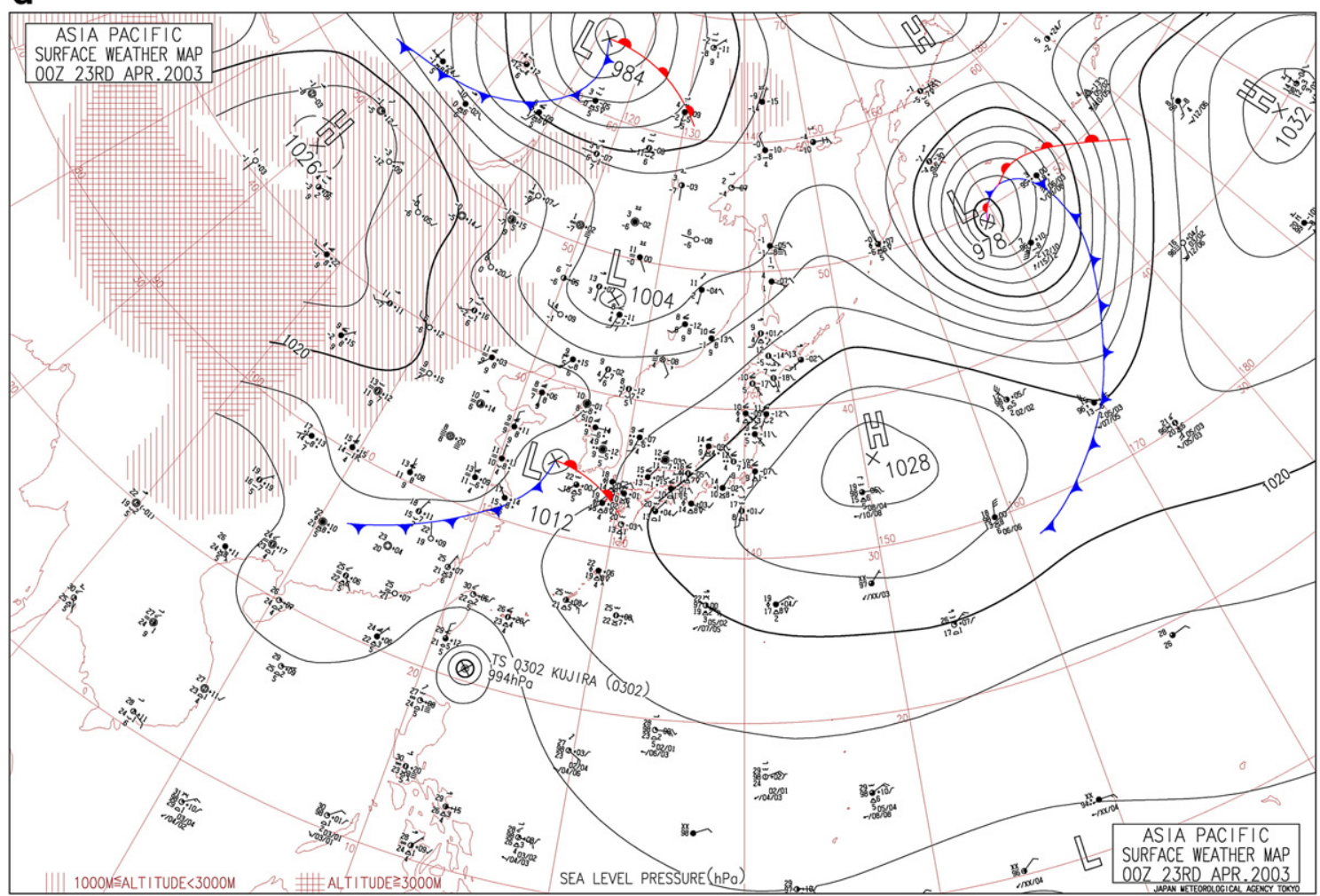

Fig. 2 (continued). 

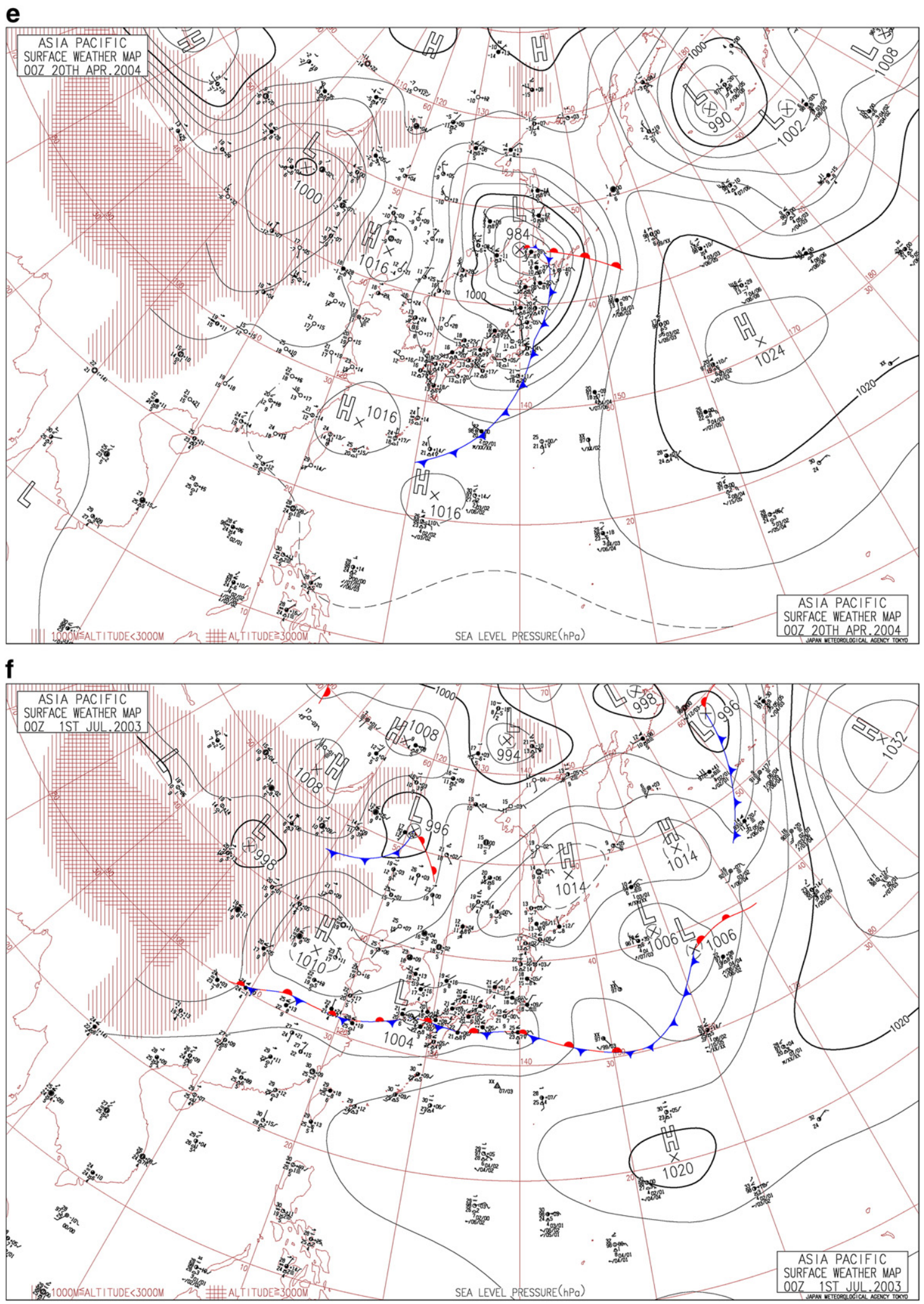

Fig. 2 (continued). 
g

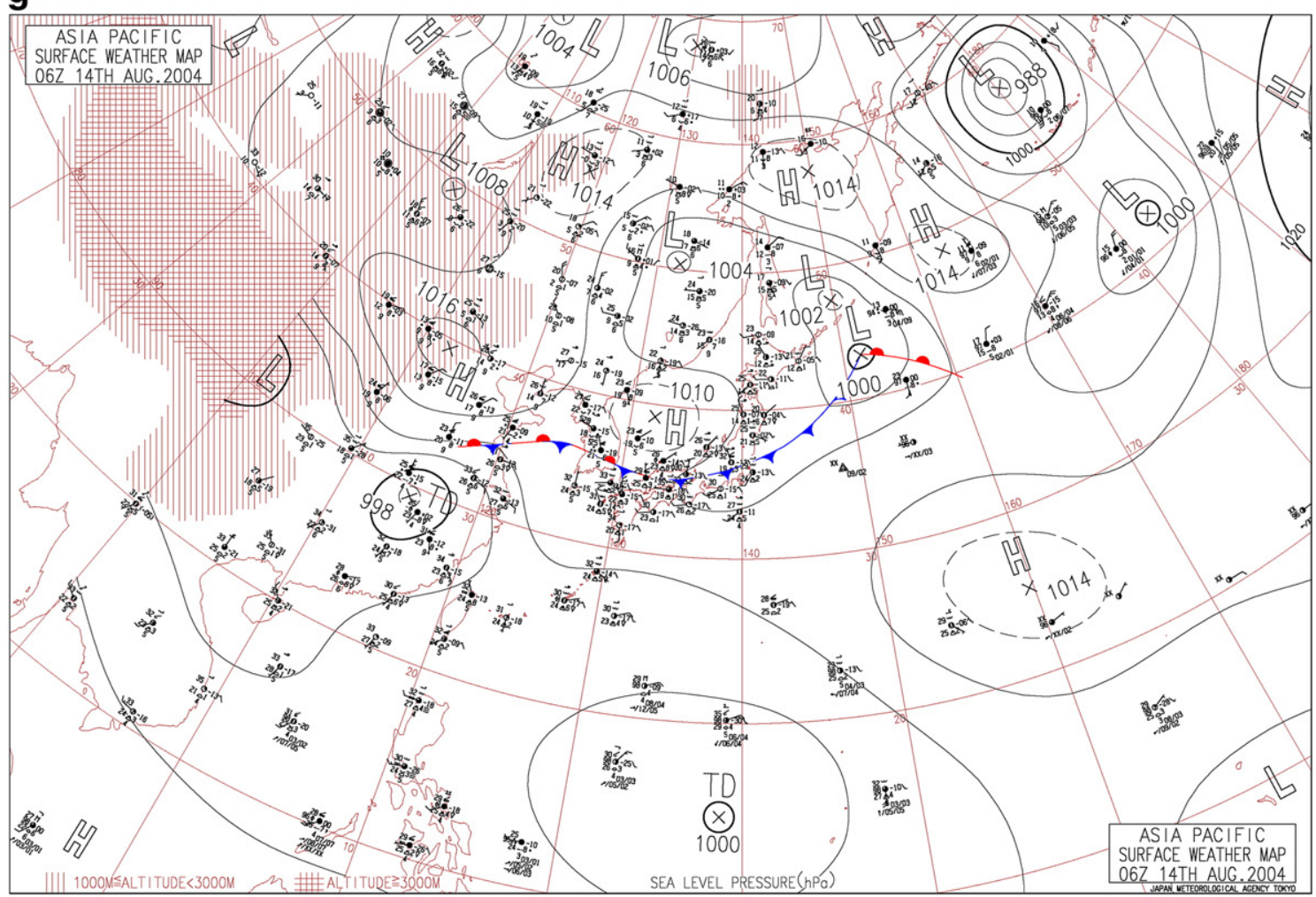

h

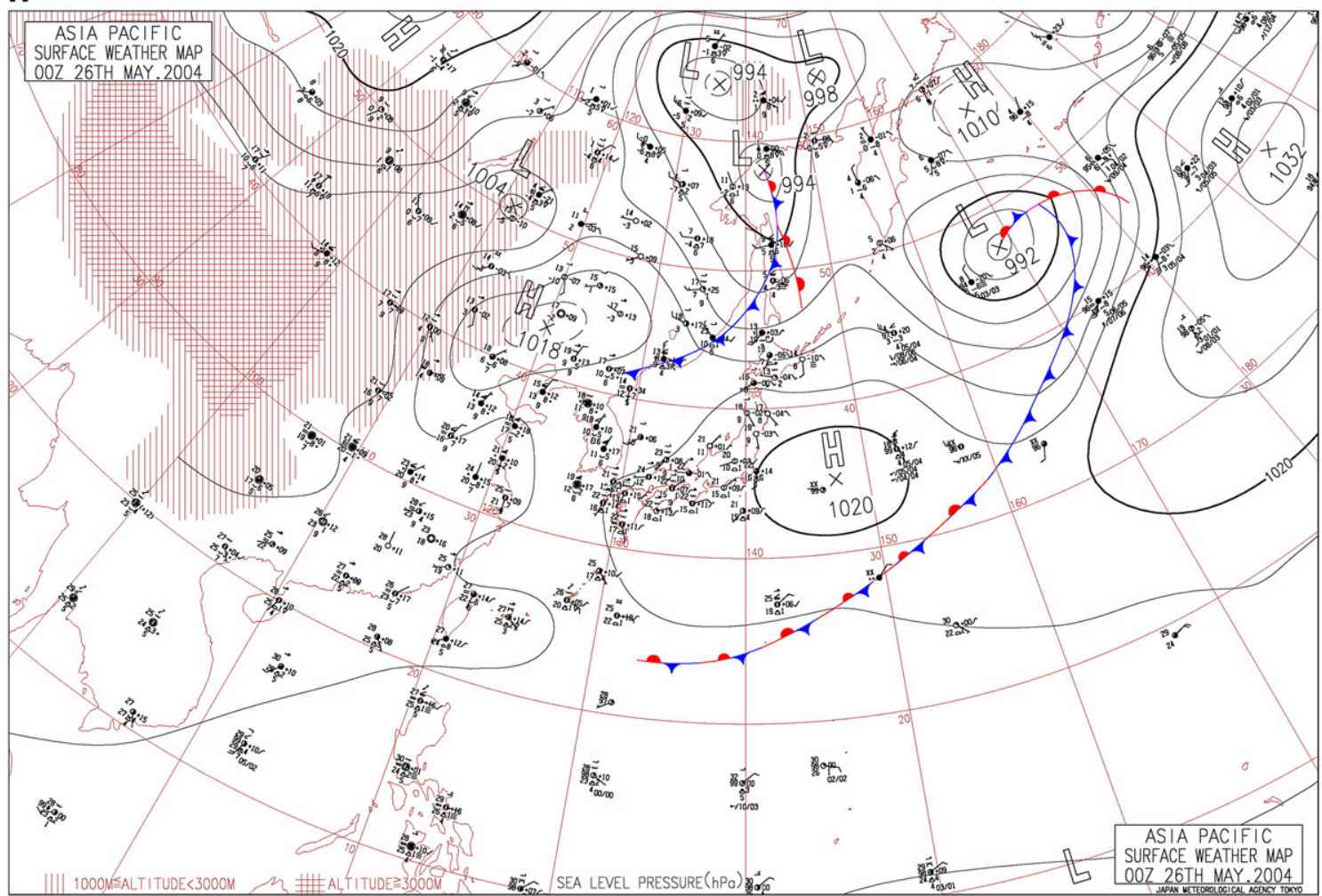

Fig. 2 (continued). 
Table 1 - Daily $\mathrm{PM}_{2.5}$ concentrations and the associated weather patterns on event days from March 2002 to February 2005

\begin{tabular}{lrcrrrr}
$\begin{array}{l}\text { Weather } \\
\text { pattern }\end{array}$ & $\begin{array}{c}\text { Event } \\
\text { days }\end{array}$ & $\begin{array}{c}\text { Days } \\
\text { with } \\
\text { invalid } \\
\text { data }\end{array}$ & $\begin{array}{c}\mathrm{PM}_{2.5} \\
\mathrm{max}\end{array}$ & $\begin{array}{c}\mathrm{PM}_{2.5} \\
\mathrm{~min}\end{array}$ & $\begin{array}{c}\mathrm{PM}_{2.5} \\
\text { avg }\end{array}$ & $\begin{array}{c}\mathrm{PM}_{2.5} \\
\text { s.d. }\end{array}$ \\
\hline HPPC & 122 & 0 & 103 & 21 & 52 & 14 \\
WAF & 98 & 0 & 98 & 13 & 49 & 16 \\
HPP & 53 & 0 & 101 & 17 & 53 & 14 \\
TYP & 34 & 1 & 90 & 28 & 46 & 12 \\
WHP & 17 & 0 & 69 & 21 & 44 & 11 \\
PHP & 15 & 1 & 66 & 10 & 40 & 12 \\
WSW & 12 & 0 & 54 & 33 & 44 & 6 \\
other & 1 & 0 & - & - & 51 & - \\
Non-event & 150 & 2 & 46 & 8 & 25 & 9 \\
days in spring & & & & & & \\
$\begin{array}{l}\text { Non-event } \\
\text { days in summer }\end{array}$ & 219 & 2 & 44 & 6 & 24 & 10 \\
$\begin{array}{l}\text { Non-event days } \\
\text { in autumn }\end{array}$ & 184 & 25 & 53 & 7 & 22 & 9 \\
$\begin{array}{l}\text { Non-event days } \\
\text { in winter }\end{array}$ & 150 & 10 & 50 & 7 & 22 & 9 \\
\hline
\end{tabular}

Note: the unit of $\mathrm{PM}_{2.5}$ concentration is in $\mu \mathrm{g} \mathrm{m}^{-3}$. A day with invalid data is the one with fewer than 16 valid hourly values in a day.

is no rainfall in the front ahead of the high-pressure system. This specific weather pattern, defined as HPP, is shown in Fig. 2(c).

In the warm (summer) season, there are four weather patterns attributed to $\mathrm{PM}_{2.5}$ events. The first type is TYP pattern in Fig. 2(d). When the typhoon is located south or southeast of Taiwan, the peripheral circulation can be the southeast wind, and Taipei is located on the lee side against SMC. In such a condition, $\mathrm{PM}_{2.5}$ events form owing to the occurrence of subsiding air. Cheng (2001) mentioned an analogous explanation for high ozone events in central Taiwan. However, there are a few high $\mathrm{PM}_{2.5}$ cases where the typhoon is not located south or southeast of Taiwan but is very near Taiwan; the prevailing wind around north Taiwan is not a southeast wind. Based on the structure of the typhoon, the proposed reasonable presumption is that Taipei is located at the subsidence area outside the center of the typhoon when the typhoon gets near Taipei. Inversion is deduced by quasi- adiabatic subsidence and pollutants accumulate in the Taipei basin. The second type is defined as WHP pattern as shown in Fig. 2(e). It occurs when there is a weak high-pressure system over Taiwan or very near Taiwan, the lower atmosphere is stable, and the pressure gradient force around Taiwan is very weak. Most of these weak high-pressure systems are from the divisions of Pacific high-pressure systems in summer, while a few are from Asian continental high-pressure systems in spring and autumn. The third type is called PHP pattern as shown in Fig. 2(f). In summer, the Pacific high-pressure system sometimes expands and stretches out to the west. If the ridge of the high-pressure system is around the northwest of Taiwan, the peripheral circulation of high-pressure is southeast, relative to Taiwan. Under this weather pattern, the Taipei basin is located on the lee side of SMC, which makes the air stream crossing SMC subside. The last type is called WSW pattern as shown in Fig. 2(g). When the prevailing wind blows very weakly from the south of Taiwan, the air stream flows through west coastal cities, which may bring industrial and urban pollutants northward. This air stream is blocked by, and could not go past Mt. Da-Twen and SMC. Pollutants thereby accumulate in the Taipei basin.

It is apparent that the daily $\mathrm{PM}_{2.5}$ concentration on event days is about twice that on non-event days as shown in Table 1. The total event days make up about one-third of the days from March 2002 to February 2005. From February to April, the Asian continental high-pressure systems appear frequently in the West Pacific about once per week (Bachmeier et al., 1996). It is noticed that HPPC, WAF, and HPP weather patterns prevail in $77 \%$ of all the event days as shown in Table 2. Although HPPC, WAF, and HPP occur during spring, autumn, and winter, these three weather patterns occur on $46 \%$ of the days from February to April. It is also noted that WAF frequently follows the HPPC weather pattern. On the other hand, TYP, WHP, PHP, and WSW weather patterns occur mainly during summer. Although almost all the $\mathrm{PM}_{2.5}$ event days are classified into seven weather patterns, an exception happened on May 26 in 2004. On that day, a stagnant front unusually remained over central Taiwan (Fig. 2(h)).

From Table 3, it is obvious that the wind speed is higher for HPP than any other event weather patterns. On the other hand, the percentage of wind speed that is less than $1.5 \mathrm{~m} \mathrm{~s}^{-1}$ at the TPE site is over $60 \%$ under HPPC and WAF weather patterns. The average wind speeds are 0.9 and $0.8 \mathrm{~m} \mathrm{~s}^{-1}$,

Table 2 - Frequency of event days in like months and pollution origins for different weather patterns from March 2002 to February 2005

\begin{tabular}{|c|c|c|c|c|c|c|c|c|c|c|c|c|c|c|c|c|}
\hline Weather pattern & Jan & Feb & Mar & Apr & May & June & Jul & Aug & Sept & Oct & Nov & Dec & Total & LRT & LRP/LP & LP \\
\hline HPPC & 17 & 22 & 20 & 23 & 13 & 4 & 0 & 0 & 2 & 3 & 9 & 9 & 122 & 0 & $122(34.5)$ & 0 \\
\hline WAF & 10 & 16 & 15 & 19 & 13 & 8 & 1 & 1 & 2 & 0 & 4 & 9 & 98 & 0 & $93(26.3)$ & $5(1.4)$ \\
\hline HPP & 12 & 5 & 3 & 1 & 4 & 0 & 0 & 0 & 3 & 12 & 3 & 10 & 53 & $53(15.0)$ & 0 & 0 \\
\hline TYP & 0 & 0 & 0 & 4 & 4 & 2 & 4 & 5 & 7 & 5 & 4 & 0 & 35 & 0 & $12(3.4)$ & $23(6.5)$ \\
\hline WHP & 0 & 0 & 0 & 1 & 3 & 2 & 3 & 5 & 3 & 0 & 0 & 0 & 17 & 0 & $2(0.6)$ & $15(4.2)$ \\
\hline PHP & 0 & 0 & 0 & 0 & 0 & 0 & 5 & 4 & 3 & 4 & 0 & 0 & 16 & 0 & 0 & $16(4.5)$ \\
\hline WSW & 0 & 0 & 0 & 0 & 0 & 3 & 2 & 6 & 1 & 0 & 0 & 0 & 12 & 0 & 0 & $12(3.4)$ \\
\hline other & 0 & 0 & 0 & 0 & 1 & 0 & 0 & 0 & 0 & 0 & 0 & 0 & 1 & 0 & $1(0.3)$ & 0 \\
\hline
\end{tabular}

Note: the column of LRT indicates the aerosol event is mainly originated from long-range transport, LRT/LP indicates the aerosol event is caused by a mix of long-range transport and local pollution, LP indicates the aerosol event is resulted from local pollution. The number in parenthesis shows percent of the corresponding pollution origin in total. 
Table 3-Hourly wind speed statistics for the classified weather patterns at four weather observatories (see Fig. 1 for geographical locations)

\begin{tabular}{|c|c|c|c|c|c|c|c|c|c|}
\hline \multirow[t]{2}{*}{$\begin{array}{l}\text { Weather } \\
\text { pattern }\end{array}$} & \multirow[t]{2}{*}{ Number } & \multicolumn{4}{|c|}{$\begin{array}{c}\text { Frequency for } \\
\text { WS }<1.5 \mathrm{~m} \mathrm{~s}^{-1}(\%)\end{array}$} & \multicolumn{4}{|c|}{$\begin{array}{c}\text { Average WS } \\
\left(\mathrm{m} \mathrm{s}^{-1}\right)\end{array}$} \\
\hline & & DS & TPE & $\mathrm{KL}$ & PJY & DS & TPE & $\mathrm{KL}$ & PJY \\
\hline HPPC & 806 & 59.3 & 64.3 & 39.6 & 3.5 & 0.9 & 0.9 & 1.7 & 5.9 \\
\hline WAF & 573 & 59.3 & 65.2 & 34.1 & 5.1 & 0.9 & 0.8 & 1.9 & 5.1 \\
\hline HPP & 338 & 40.5 & 13.1 & 13.7 & 0.0 & 1.5 & 3.0 & 3.9 & 7.4 \\
\hline TYP & 143 & 62.3 & 47.5 & 20.7 & 5.0 & 0.9 & 1.3 & 2.9 & 7.0 \\
\hline WHP & 57 & 67.9 & 30.4 & 32.1 & 0.0 & 0.7 & 2.0 & 2.0 & 5.0 \\
\hline PHP & 41 & 61.5 & 48.7 & 41.0 & 2. 6 & 0.8 & 1.5 & 1.7 & 5.6 \\
\hline WSW & 35 & 76.5 & 35.3 & 38.2 & 0.0 & 0.4 & 1.7 & 1.8 & 6.7 \\
\hline
\end{tabular}

respectively, which are less than those of other weather patterns. The aerosol field observation conducted in this study was under the influence of HPPC and WAF weather patterns and will be described in Section 3.3.

From the previous description of the characteristics of event weather pattern, we can infer that all types of weather patterns, except the HPP pattern, are related to the influence of the complex terrain. Here, we will raise two examples to elaborate the effects of terrain blocking in the Taipei basin. First, southeast and east winds were observed at the PJY and TPE sites, respectively, for the HPPC, TYP, WHP, and PHP weather patterns (not shown). For the TPE site, it is thought that the observed east wind must have either originated from the strong prevailing southeast wind that climbs over SMC, or the weak southeast wind that skirts north of SMC, passes through the Kee-Lung valley, and reaches Taipei. Whichever way it goes, it depends on the intensity of the prevailing southeast wind and vertical stability. The second example is found in many cases when the prevailing west wind is observed at the PJY site for WAF and WSW weather patterns; the east wind is then observed at the TPE site. Under these circumstances, the south or southwest wind blows at west Taiwan for the WAF and WSW patterns. The prevailing south or southwest wind climbs over Lin-Co Plateau and enters the Taipei basin northeastward. Because the Kee-Lung Valley in the northeast is not wide enough for this air mass to pass through to the sea in a short time, a reverse east wind in the Taipei basin is created because of the blocking of SMC.

\subsection{Weather patterns and pollution origins}

Several studies (Chung et al., 1996; Shimohara et al., 2001; Jordan et al., 2003; Lin et al., 2005) pointed out that the Asian outflow was transported to the western Pacific with the moving Asian high-pressure system during cold seasons. When a high-pressure system moves to the West Pacific, the HPPC weather pattern begins to influence Taiwan, since HPPC originates from China, and because Taipei is located on the lee side of SMC under the southeast peripheral circulation. The Asian continental aerosol transported by the moving air mass combines with the Taipei local pollutants on the lee side of SMC. Therefore, $\mathrm{PM}_{2.5}$ in Taipei should be the result of LRT/LP (a mix of LRT and LP). Soon after the HPPC weather pattern, another Asian continental high-pressure system and its leading edge, i.e., cold front, approaches Taiwan, as usual. WAF succeeds in becoming the influencing weather pattern. Because the cold front separates warm and cold air masses ahead and after, $\mathrm{PM}_{2.5}$ in Taipei (which is located ahead of the front) may only be contributed by LP. However, the $\mathrm{PM}_{2.5}$ sulfate level at the background site is quite high as shown in Table 4. Therefore, the pollution level in the WAF weather pattern should be from LRT/LP. Usually, high-pollution concentration from LP is related to low wind speed. However, for the HPP weather pattern, a high $\mathrm{PM}_{2.5}$ level is observed with the strong northeast wind when the strong high-pressure air mass reaches Taipei. Pollutants originally accumulating in Taipei should be transported quickly to the south. Thus, the HPP weather pattern should only be attributed to LRT. Sometimes, the HPP affects Taiwan right after the occurrence of the WAF weather pattern. From the previous description of the

Table 4 - Averages and mass fractions of the analyzed $\mathrm{PM}_{2.5}$ components and the estimated organic matter (OM) at the TAS and BTJ sites during intensive aerosol observation period

\begin{tabular}{|c|c|c|c|c|c|c|c|c|}
\hline & \multicolumn{4}{|c|}{ TAS (urban) } & \multicolumn{4}{|c|}{ BTJ (background) } \\
\hline & HPPC & WAF & WHP & Non-event & HPPC & WAF & WHP & Non-event \\
\hline EC & $3.8(7.7 \%)$ & $3.8(7.6 \%)$ & $3.1(7.0 \%)$ & $2.3(7.2 \%)$ & $2.3(7.4 \%)$ & $1.9(6.2 \%)$ & $1.1(4.1 \%)$ & $1.5(5.2 \%)$ \\
\hline $\mathrm{OM}$ & $15.7(31.5 \%)$ & $16.5(33.0 \%)$ & $13.5(33.3 \%)$ & $8.9(27.7 \%)$ & $7.4(23.6 \%)$ & $5.8(18.9 \%)$ & $5.4(19.6 \%)$ & $6.0(20.7 \%)$ \\
\hline nss $\mathrm{SO}_{4}{ }^{2-}$ & $13.4(26.7 \%)$ & $13.3(26.5 \%)$ & $11.4(25.5 \%)$ & $10.6(33.2 \%)$ & $13.1(41.4 \%)$ & $12.038 .9 \%)$ & $7.1(25.1 \%)$ & $9.0(31.1 \%)$ \\
\hline Sea salt $\mathrm{SO}_{4}^{2-}$ & $0.1(0.2 \%)$ & $0.1(0.1 \%)$ & $0.1(0.2 \%)$ & $0.1(0.3 \%)$ & $0.1(0.3 \%)$ & $0.1(0.3 \%)$ & $0.4(1.3 \%)$ & $0.1(0.5)$ \\
\hline $\mathrm{NO}_{2}^{-}+\mathrm{NO}_{3}^{-}$ & $3.0(5.9 \%)$ & $3.3(6.7 \%)$ & $2.7(6.0 \%)$ & $2.4(7.4 \%)$ & $0.8(2.4 \%)$ & $0.8(2.6 \%)$ & $1.8(6.4 \%)$ & $0.8(2.7 \%)$ \\
\hline $\mathrm{NH}_{4}^{+}$ & $5.3(10.6 \%)$ & $5.5(10.9 \%)$ & $4.9(11.0 \%)$ & $4.1(12.7 \%)$ & $3.9(12.5 \%)$ & $3.2(10.5 \%)$ & $2.2(7.9 \%)$ & 2.7 (9.4\%) \\
\hline Minor water-soluble ions & $1.8(3.5 \%)$ & $1.5(3.0 \%)$ & $1.6(3.5 \%)$ & $1.7(5.2 \%)$ & $1.3(4.1 \%)$ & $1.5(4.8 \%)$ & $3.7(13.2 \%)$ & $1.7(5.7 \%)$ \\
\hline Unresolved components & $7.0(14.0 \%)$ & $6.2(12.3)$ & $7.3(16.5 \%)$ & $2.0(6.3 \%)$ & $2.6(8.2 \%)$ & $5.5(17.8)$ & $6.1(21.9)$ & $7.2(24.7)$ \\
\hline $\mathrm{PM}_{2.5}$ & $50.0(100 \%)$ & $50.2(100 \%)$ & $44.5(100 \%)$ & $32.0(100 \%)$ & $31.5(100 \%)$ & $30.8(100 \%)$ & $27.8(100 \%)$ & $29.0(100 \%)$ \\
\hline
\end{tabular}

Note: the unit of averages in this Table is in $\mu \mathrm{g} \mathrm{m}^{-3}$. Numbers in parentheses are mass fractions of either analyzed or estimated aerosol components. The weather pattern in the daytime of April 17 and 21, 2004 was HPPC. WAF weather pattern covered the nighttime of April 17, 21, and 22, 2004 and the daytime of April 18 and 22, 2004. WHP was the weather pattern for the daytime and nighttime of April 20, 2004. The daytime starts from 08:00 to 20:00 and nighttime begins from 20:00 to 8:00 next day. For the TAS site, OM (organic matter) $=\mathrm{OC} \times 1.6$. For the BTJ site, $\mathrm{OM}=\mathrm{OC} \times 1.4$ followed by the suggestion from Turpin and $\mathrm{Lim}(2001)$. Analyzed minor water-soluble ions include $\mathrm{Li}^{+}, \mathrm{K}^{+}, \mathrm{Mg}^{+2}, \mathrm{Ca}^{+2}, \mathrm{Na}^{+}, \mathrm{F}^{-}, \mathrm{Br}^{-}$, $\mathrm{Cl}^{-}$, and $\mathrm{PO}_{4}^{-3}$. 
feature of the PHP weather pattern, the event formation mechanism under PHP in the warm season is very similar to the HPPC weather pattern in the cold season. The prevailing wind around Taiwan is the southeast wind in both patterns. The difference is that the peripheral circulations of PHP and HPPC weather patterns come from the Pacific high-pressure system in summer and the Asian continental high-pressure system in winter, respectively. Furthermore, for the formation of the PHP weather pattern, the Pacific high-pressure ridge should be located at the northwest of Taiwan, and thus the prevailing wind could be the southeast wind. Since the background aerosol level is very low in summer, the $\mathrm{PM}_{2.5}$ for the PHP weather pattern should be contributed by LP only. Table 1 shows that the average daily $\mathrm{PM}_{2.5}$ level is about $40 \mu \mathrm{g}$ $\mathrm{m}^{-3}$ for PHP, which is the lowest in all weather patterns. It indicates that local pollution is not serious in summer. For the TYP weather pattern, the presence of the Pacific high-pressure ridge near Taipei makes typhoons move along the peripheral circulation of the Pacific high air mass before approaching Taiwan. The differences between the PHP and TYP weather patterns are the location of the Pacific high-pressure ridge and the presence of strong but low-pressure turbulence, i.e., typhoons. It is noted that Taipei is located on the lee side of SMC when an upwind air stream comes from the peripheral circulation of a typhoon situated at the south or southeast of Taipei. The southeast wind prevails around north Taiwan resulting in the lee side subsidence occurring in the Taipei basin. For the WHP weather pattern, when a weak highpressure system is over Taipei or moves quite near Taipei in summer, air pollution is mainly caused by strong inversion or light wind. It is plainly derived that pollution in the WHP weather pattern should be from LP. However, two out of a total 17 event days occurred when high-pressure air masses came from the Asian continent, and thus the WHP weather pattern can sometimes be from LRT/LP, since the background $\mathrm{PM}_{2.5}$ sulfate level is high (see Table 4). In summer, when the south or southwest wind is weak, Mt. Da-Twen and SMR trap the weak southwest wind that flows into the Taipei basin. The high $\mathrm{PM}_{2.5}$ level in Taipei may be caused by the local calm wind or by the transport from central Taiwan. Therefore, the pollution in the WSW weather pattern should be from LP only. The frequency of various event weather patterns in each month and the pollution origin in terms of LRT, LP, or LRT/LP are shown in Table 2. Based on the statistics in Table 2, we calculated that the contribution by LRT was $15 \%$ and by LP was $20 \%$. We noted that $65 \%$ of the aerosol event days were contributed by LRT/LP. This type of aerosol event was brought by the air mass originating from the Asian continent, but was aggravated in the Taipei basin owing to terrain blocking. Quantifying pollution based on where it originated can be achieved by using numerical modeling (ApSimon et al., 2001; Hsu et al., 2006) or trajectory cluster analysis (Dorling and Davies, 1994; Harrison et al., 2000; Abdalmogith and Harrison, 2005; Borge et al., 2007). Lin et al. (2004) developed an objective method to analyze the air quality in the Taipei basin from November 1999 to May 2000, and from November 2000 to May 2001. They showed the frequency of LP was $71.7 \%$ but about one-third to two-thirds of the $\mathrm{PM}_{10}$ during LP cases can be attributed to LRT. When taking LRT/LP into account, they estimated the contribution of LRT to $\mathrm{PM}_{10}$ in northern Taiwan during winter and spring to be in the range of $50 \%$ to $75 \%$. This frequency estimation for LRT/LP agrees well with the statistics shown in Table 2.

\subsection{The weather patterns during the intensive aerosol observation period}

To help analyze the monitored data, an intensive aerosol observation study was held in the Greater Taipei area from April 14 to 23, 2004. Based on this study, aerosol components and influencing factors are discussed under the identified weather patterns. There were two events as indicated by the continuous $\mathrm{PM}_{2.5}$ monitoring data in Fig. 3. The first event was from April 17 to 18, and the second one was from April 20 to 22. From the size-resolved 12-hr average of aerosol mass concentration (Fig. 4), it was apparent that the $\mathrm{PM}_{2.5}$ levels in the urban (TAS site) and rural (SJ site) sites were much higher than that in the background site (BTJ site) during event days. Based on the definition of weather pattern, trend of wind direction, and $\mathrm{PM}_{2.5}$ variation trend, April 17 and 21 were determined as HPPC patterns, and April 18 and 22 were identified as WAF patterns. Meanwhile, April 20 was judged as a WHP pattern, which was

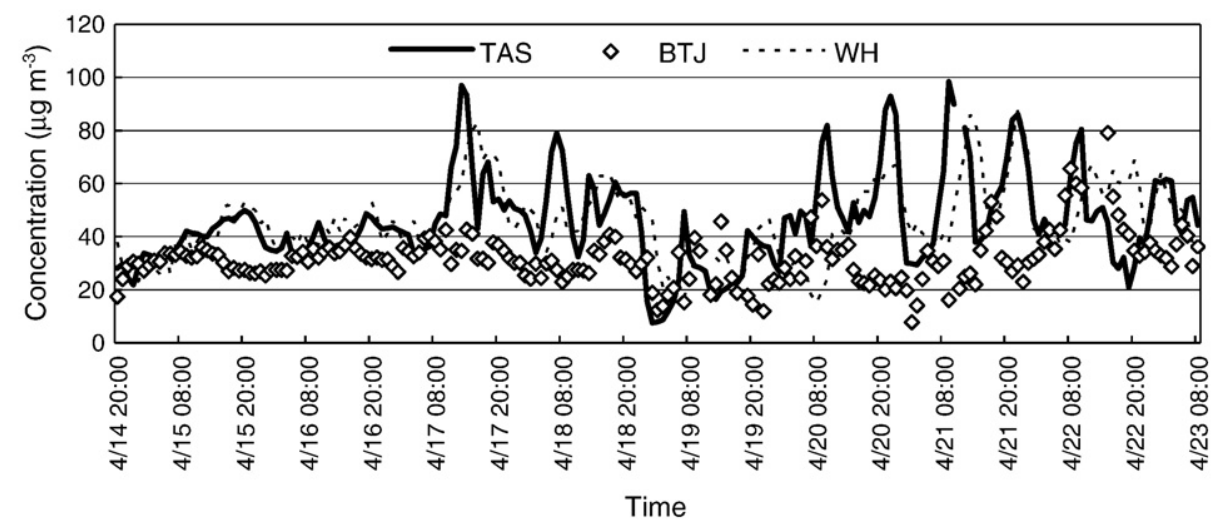

Fig. 3-Time series of hourly $\mathrm{PM}_{2.5}$ mass concentration at the TAS (urban), WH (rural), and BTJ (background) sites during intensive aerosol observation period. 


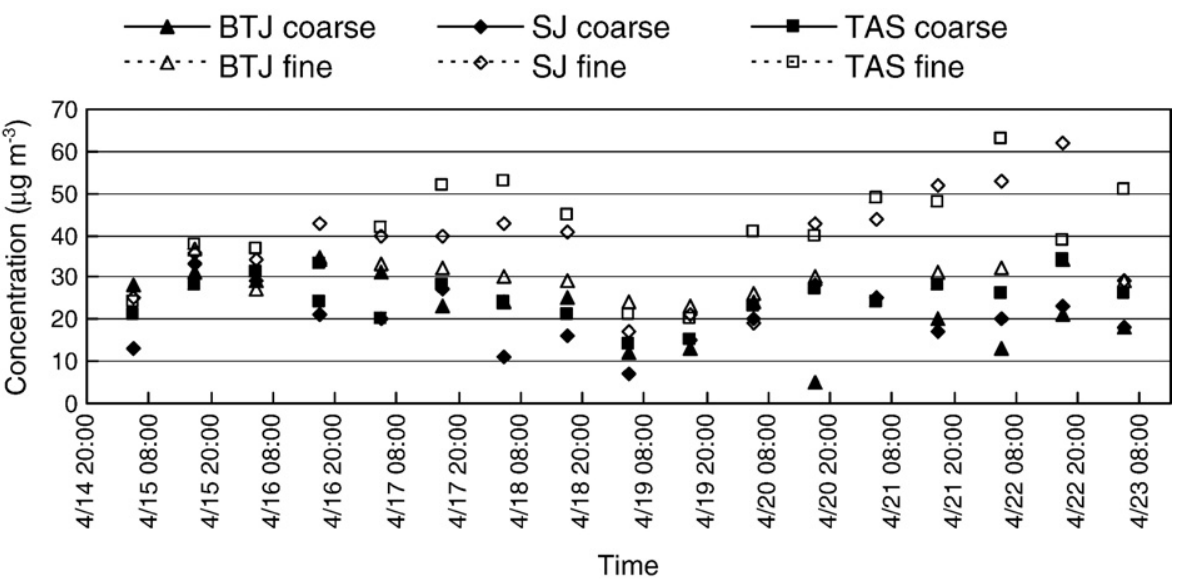

Fig. 4-12-hr averages of coarse ( $\left.\mathrm{PM}_{10-2.5}\right)$ and fine $\left(\mathrm{PM}_{2.5}\right)$ aerosol mass concentrations at the TAS (urban), SJ (rural), and $\mathrm{BTJ}$ (background) sites.

the sole case in spring in three years but also one of the few cases showing that the weak high-pressure system came from the Asian continent. Since the $\mathrm{PM}_{10}$ concentration monitored at 12 air quality sites set up by TEPA (data not shown) and the TAS site in the Taipei basin was above $100 \mu \mathrm{g} \mathrm{m}^{-3}$ during event days, the TAS site should be able to represent the air quality in Taipei.

3.4. The first aerosol event and the wind field during the observation period

Wind speed at the TPE (\#7 in Fig. 1) site began to be less than $1 \mathrm{~m} \mathrm{~s}^{-1}$ (Fig. 5) from the early hours of April 17. At the same time, the Asian continental high-pressure system moved to the West Pacific (Fig. 6(a)). The high-pressure center moved from eastern China to the waters between Taiwan, Korea, and Japan. The peripheral circulation blew clockwise northwesterly to Taiwan (Fig. 6(b)). The surface pressure on the lee side (\#7 in Fig. 1) of SMC was less than the upwind area (\#11 in Fig. 1) during the daytime of April 17 (Fig. 7). The smaller surface pressure on the lee side of SMC indicates the effect of terrain blocking of SMC. Usually, at night, the thermal effect is not as strong as the dynamic effect, which makes the temperature in the lower atmosphere not well mixed. We believe that the insolation on the ground for about an hour

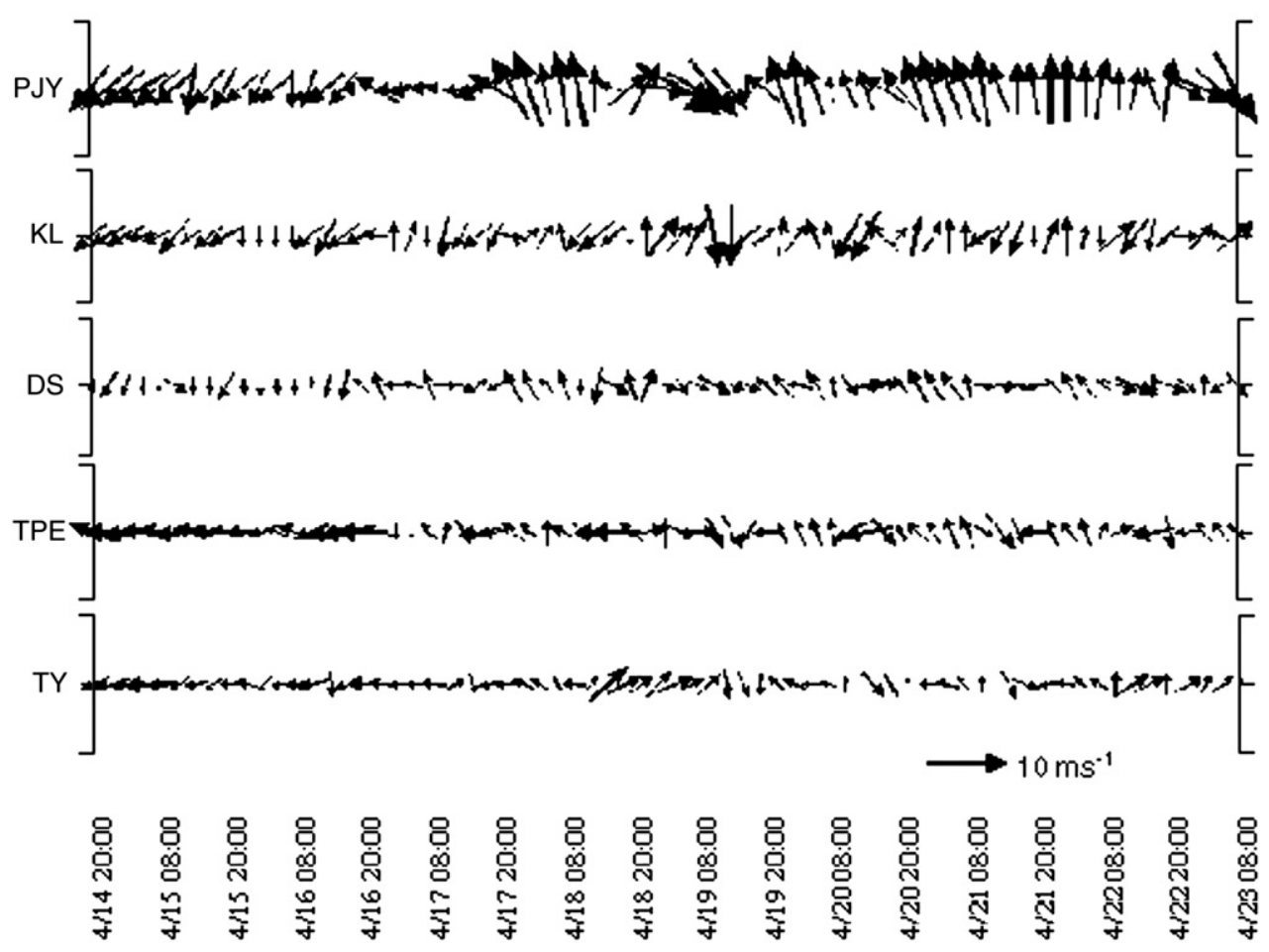

Fig. 5-Time series of wind vectors at the different weather observatories (PJY: \#10, KL: \#9, DS: \#8, TPE: \#7, TY: \#5 in Fig. 1) during intensive aerosol observation period. 

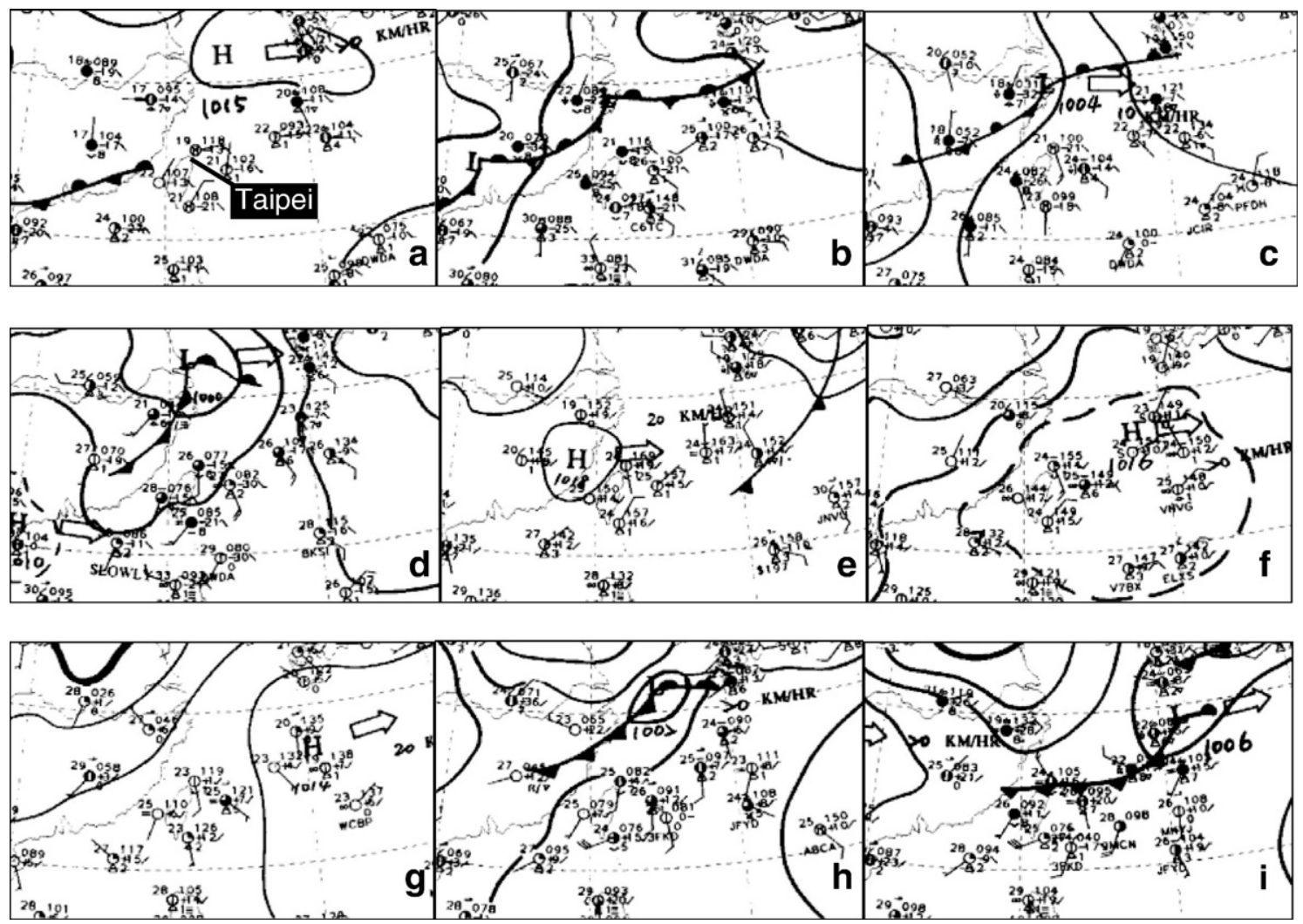

Fig. 6-Selected surface weather maps during intensive aerosol observation period in 2004 (a) 02:00 on April 17, (b) 14:00 on April 17, (c) 02:00 on April 18, (d) 14:00 on April 18, (e) 08:00 on April 20, (f) 08:00 on April 21, (g) 20:00 on April 21, (h) 20:00 on April 22, (i) 08:00 on April 23. All maps were promulgated by Taiwan Central Weather Bureau (http://www.cwb.gov.tw/).

should not change the vertical temperature profile too much. Thus, we may consider that radiosonde data at 08:00 can represent the vertical temperature structure before sunrise. From Fig. 8(a), it is obvious that the boundary layers from 750 to $1000 \mathrm{~m}$ on April 15 and lower than $750 \mathrm{~m}$ on April 17 were quite stable. From Fig. 5, it is shown that the former was caused by the subsidence of the Asian continental highpressure system. The approach of the high-pressure system also increased the wind speed at the PJY, KL, and TPE sites. The latter was from adiabatic warming caused by the lee side subsidence because the prevailing southeast wind climbed over SMC. This is determined by the observed strong east to southeast wind at the PJY site and the weak wind at the TPE site. Also, the relatively high and low pressures on the upwind and lee sides of SMC were the clues. It should be noticed that even though a relatively low pressure was observed in the Taipei basin at around 20:00 on April 16 and 19, the prevailing wind observed at the PJY site was east or southeast wind, and it should be blocked by SMC. However, the east wind at the TPE site was about $2-5 \mathrm{~m} \mathrm{~s}^{-1}$. Thus, it is supposed that a certain amount of air mass climbed over SMC and blew into the Taipei basin as a result of the observed high wind speed. $\mathrm{PM}_{2.5}$ was

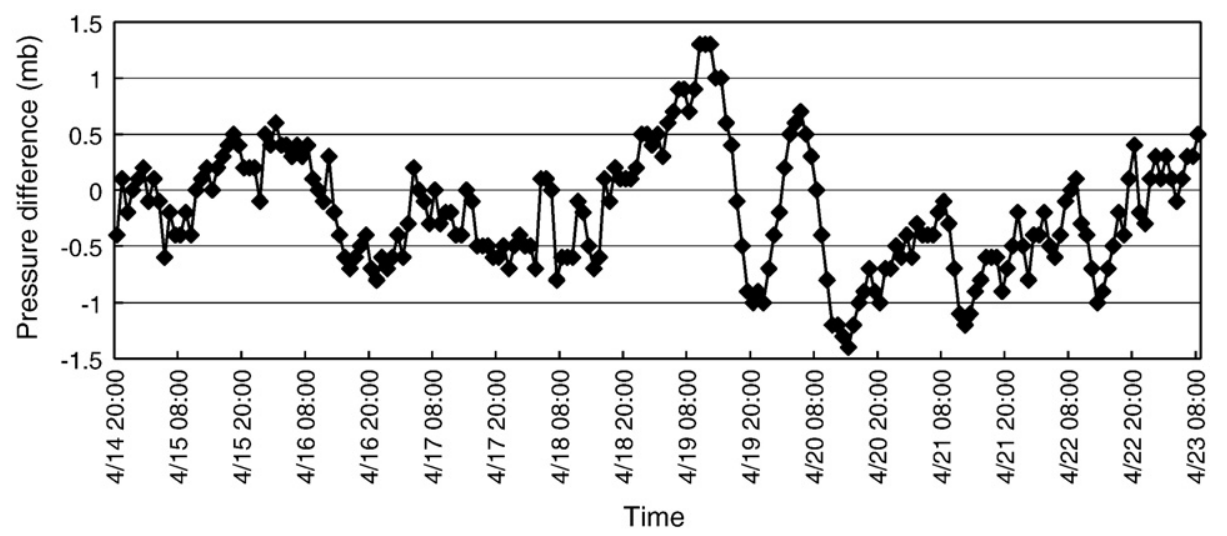

Fig. 7-Pressure differences calculated from values measured at the leeward TPE site (\#7 in Fig. 1) minus those at the windward IL site (\#11 in Fig. 1) during April 14-23, 2004. 
a
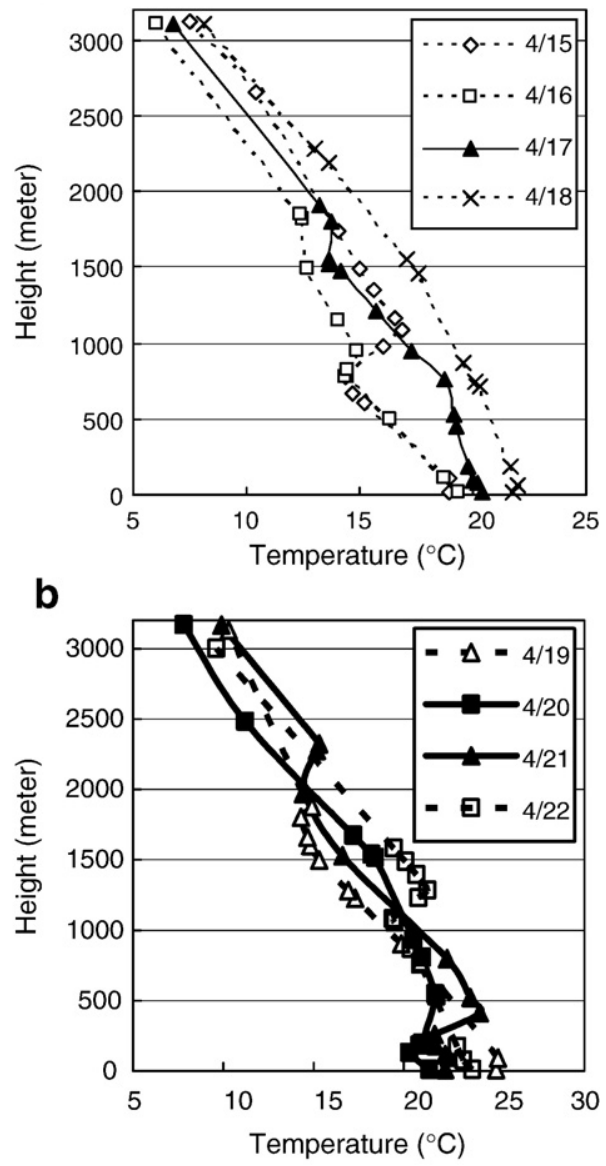

Fig. 8-Vertical temperature profile at the BC site (\#6 in Fig. 1) at 08:00 during April 15-22, 2004.

not easy to accumulate in the basin under the circumstances. Meanwhile, the $\mathrm{PM}_{2.5}$ concentration at the TAS site (\#1, Fig. 1) began to increase after 08:00 on April 17. This could be due to emissions from traffic sources. $\mathrm{PM}_{2.5}$ reached $97 \mu \mathrm{g} \mathrm{m}^{-3}$ at 13:00, and decreased to below $60 \mu \mathrm{g} \mathrm{m}^{-3}$ after 18:00. From Fig. 5, the prevailing east wind observed at the PJY site (\#10 in Fig. 1) during the daytime of 17 April gradually changed to the south wind. The wind speed at the TPE site once increased to 3-4 $\mathrm{m} \mathrm{s}^{-1}$ (Fig. 5) at night, and $\mathrm{PM}_{2.5}$ concentration was reduced accordingly (Fig. 3).

The cold front formed in south China approached Taiwan on April 18. The prevailing southeast wind (Fig. 6(b)) turned into a south wind around Taiwan at 2:00 and 14:00 on April 18 as shown in Fig. 6(c) and (d), respectively. In the morning of April 18, the south wind turned into a southwest wind and the wind speed at the TPE site decreased to less than $1 \mathrm{~m} \mathrm{~s}^{-1}$ (Fig. 5). The $\mathrm{PM}_{2.5}$ concentration at the TAS site increased to $79 \mu \mathrm{g} \mathrm{m}^{-3}$ (Fig. 3) at 07:00 on April 18. Turning to the west coast of Taiwan, it is shown in Fig. 5 that the southwest wind was observed at the TY site at 11:00 on April 18 and wind speed almost reached $4.6 \mathrm{~m} \mathrm{~s}^{-1}$. Comparing the $\mathrm{PM}_{10}$ variation trend between the TY and TAS sites in Fig. 9(a), one can infer that the $\mathrm{PM}_{10}$ was transported northeastward from the TY to the TAS sites.
3.5. The second aerosol event and wind field during the observation period

At 08:00 on April 20, a weak high-pressure system moved over Taiwan (Fig. 6(e)). High-pressure subsidence caused a stable atmosphere below $500 \mathrm{~m}$ in the Taipei basin (Fig. 8 (b)). It was verified that the wind speed at the TPE site in the morning of April 20 was about $1 \mathrm{~m} \mathrm{~s}^{-1}$. Thus, the diffusion of pollutants was poor at the TAS site (Fig. 3). The $\mathrm{PM}_{2.5}$ concentration at the TAS site was $82 \mu \mathrm{g} \mathrm{m}^{-3}$ at 10:00 and decreased afterward owing to the increase of the wind speed. Although the wind speed increased in the daytime, it went below $1 \mathrm{~m} \mathrm{~s}^{-1}$ again from 19:00 to 21:00. The $\mathrm{PM}_{2.5}$ concentration was responsive to reach above $65 \mu \mathrm{g} \mathrm{m}^{-3}$ from 20:00 to 23:00. (Fig. 3). On April 21, the high-pressure center moved to the south of Japan (Fig. 6(f)). The prevailing southeast wind heading for SMR made the surface pressure on the upwind area higher than that on the lee side area (Fig. 7). Just as on April 17, the lower atmosphere in the Taipei basin was quite stable below $500 \mathrm{~m}$ (Fig. 8(b)). The $\mathrm{PM}_{2.5}$ concentration was once more above $65 \mu \mathrm{g} \mathrm{m}^{-3}$ from 08:00 to $13: 00$ and from 20:00 to 24:00 (Fig. 3). Meanwhile, the wind speed was below $2 \mathrm{~m} \mathrm{~s}^{-1}$ during this period. It was evident that the high $\mathrm{PM}_{2.5}$ concentration observed at the TAS site was closely related to a stable atmosphere of below $500 \mathrm{~m}$ and the low wind speed on the lee side of SMC. The high-pressure system continued to move eastward and became part of Pacific high-pressure system (Fig. 6(e)). At that moment, the cold front formed at eastern China slowly moved

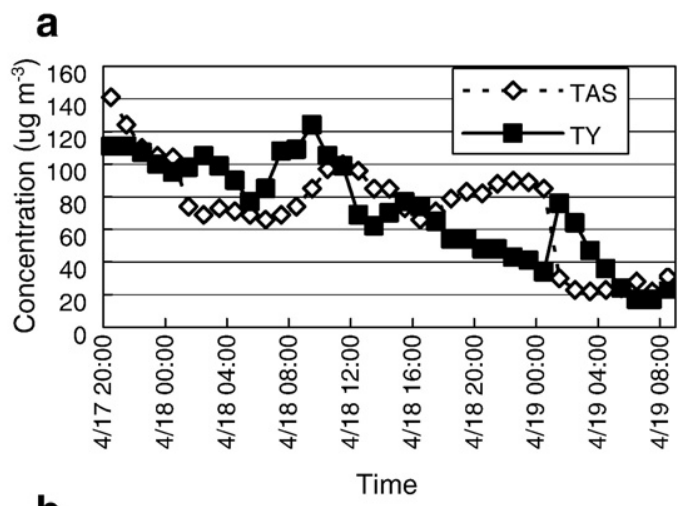

b

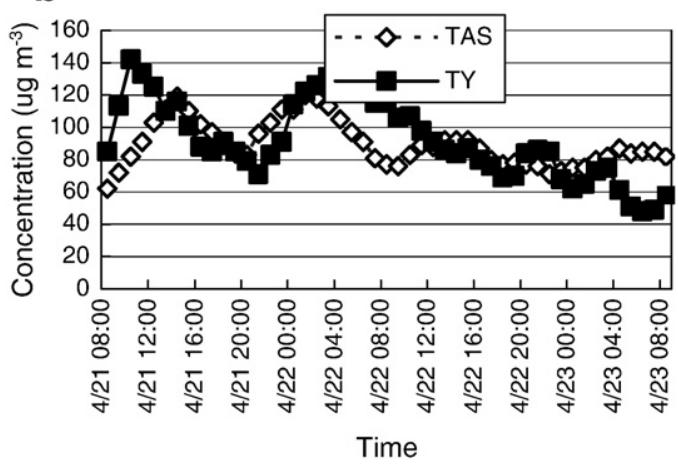

Fig. 9-Time series of $\mathrm{PM}_{10}$ mass concentrations monitored at the TAS (\#1 in Fig. 1) and TY (\#5 in Fig. 1) sites under the HPPC (April 17 and 21 in 2004) and WAF weather patterns (April 18 and 22 in 2004). 
southeastward. The prevailing wind became the south wind around Taiwan on April 22 (Fig. 6(h)). From Fig. 5, it is shown that a very weak southwest wind prevailed at the TY site at 10:00 on April 22. Not long after, a south wind was observed at the TPE, KL, and PJY sites. The $\mathrm{PM}_{2.5}$ variation trend at the TAS site was in agreement with that at the TY site (Fig. 9(b)). It could be derived that the $\mathrm{PM}_{2.5}$ observed at the TAS site was a combination of the local emissions in the Taipei basin and what was transported from west coastal cities of Taiwan. When the cold front reached Taiwan, the prevailing wind became west to northwest as observed at the PJY site (Fig. 5). The aerosol observation ceased because of the rainfall brought by the cold front (Fig. 6(i)).

\subsection{Temperature effects on pollution dispersion}

During the $\mathrm{PM}_{2.5}$ events (the first event was during April 17-18, the second one was during April 20-22) discussed previously, a sea breeze prevailed at the seashore DS (northwest wind) and KL (northeast wind) sites as shown in Fig. 5. Wind speed was also observed to increase in the afternoon at the TPE site. Fig. 3 shows that the $\mathrm{PM}_{2.5}$ level decreased owing to wind dilution at the TAS and WH sites in the afternoon during April 20-22. However, this did not occur during April 17-18. The daily peak temperature recorded was $24.7,29.6,32.5,33.1$, and $33.1^{\circ} \mathrm{C}$ on April 17, 18, 20, 21, and 22, respectively. It demonstrates that higher temperature in the second than in the first event resulted in a stronger thermal turbulence for a better $\mathrm{PM}_{2.5}$ dispersion in the afternoon.

\subsection{Aerosol properties and source contributions}

Nearly all the samples collected at the urban (TAS) and the suburban (SJ) sites had very similar chemical component distributions. Thus, only the urban site and the background (BTJ) site are compared in Table 4. In all sampling periods, $\mathrm{PM}_{2.5}$ sulfate concentration at the TAS site is higher than the BTJ site, except for the nighttime of April 16 and 19 (Fig. 10). During nighttime of April 16 and 19, the leading edge of the Asian continental high pressure system moved southeastward and passed over north Taiwan. The position of the BTJ site was north of the TAS site, and this is the reason for the slightly higher $\mathrm{PM}_{2.5}$ sulfate concentration at the BTJ site than at the TAS site. In all other sampling periods, since the dispersion condition was not more preferable inside the basin than outside, the $\mathrm{PM}_{2.5}$ sulfate concentration was higher at the TAS site than at the BTJ site. On average, $\mathrm{PM}_{2.5}$ sulfate made up $29 \%$ and $34 \%$ of $\mathrm{PM}_{2.5}$ at the TAS and BTJ sites, respectively, during the observation period. It should be noted that $\mathrm{PM}_{2.5}$ sulfate is the major component of $\mathrm{PM}_{2.5}$, especially for the BTJ site. Furthermore, it was estimated that $\mathrm{PM}_{2.5}$ nss-sulfate made up $98.9 \%$ to $99.7 \%$ and $94.6 \%$ to $94.8 \%$ of $\mathrm{PM}_{2.5}$ sulfate at the TAS and BTJ sites, respectively. Thus, almost all the $\mathrm{PM}_{2.5}$ sulfates were initially from photochemical reactions and were then transported to the Taipei basin. Since there are very few sulfur dioxide or sulfate sources in the Taipei basin, it could be asserted that $\mathrm{PM}_{2.5}$ sulfate came with the air mass that passed over Taiwan. During the observation period, all weather systems moved from mainland China. Thus, we could suppose that mainland China was the main source of $\mathrm{PM}_{2.5}$ sulfate observed in north Taiwan.

On the average, for $\mathrm{PM}_{2.5}$ nitrate, the ratio of the TAS to BTJ sites was $6.5( \pm 4.0)$ in the nighttime. Especially in the nighttime of April 17 and 21, the ratio almost reach 12. However, in the daytime, the $\mathrm{PM}_{2.5}$ nitrate concentration at the TAS site was not always higher than that at the BTJ site. It is noted that the $\mathrm{PM}_{2.5}$ nitrate concentration at the TAS site made up $17.6 \%$ of $\mathrm{PM}_{2.5}$ in the nighttime and $5.7 \%$ in the daytime. The correlation coefficient $\left(r^{2}\right.$, also applied in the following context) between $\mathrm{PM}_{2.5}$ nitrate and $\mathrm{PM}_{2.5}$ was 0.65 at the TAS site. Moreover, the correlation coefficient of $\mathrm{Na}^{+}$and $\mathrm{NO}_{3}^{-}$ almost reached up to 0.95 at the BTJ site, which was much higher than 0.47 at the TAS site. It is known that the compound form for nitrate usually consists of $\mathrm{NH}_{4} \mathrm{NO}_{3}$ and/ or $\mathrm{NaNO}_{3}$ and vehicle exhausts are the major emission source of $\mathrm{NO}_{x}$ in the Taipei basin. Thus, it may suggest that the major compound form for nitrate was $\mathrm{NaNO}_{3}$ at the BTJ site and a mix of $\mathrm{NH}_{4} \mathrm{NO}_{3}$ and $\mathrm{NaNO}_{3}$ at the TAS site.

Except in the nighttime of April 14 and 18, the $\mathrm{PM}_{2.5}$ ammonium concentration at the TAS site was higher than that at the BTJ site. The ratio of the TAS to BTJ sites was $1.7( \pm 0.7)$ on the average. At the TAS site, the correlation coefficient of $\mathrm{NH}_{4}^{+}$ with $\mathrm{SO}_{4}^{2-}$ and $\mathrm{NH}_{4}^{+}$with $\mathrm{NO}_{3}^{-}$were 0.73 and 0.13 , respectively. At the BTJ site, those two coefficients were 0.92 and -0.14 , respectively. Thus, it could be derived that $\mathrm{PM}_{2.5}$ ammonium should mostly have the form of $\left(\mathrm{NH}_{4}\right)_{2} \mathrm{SO}_{4}$ (Chen et al., 2003) or $\mathrm{NH}_{4} \mathrm{HSO}_{4}$ at both sites.

During April 17-18 and April 21-22, the land-sea breeze was very significant both at the seashore KL and DS sites. It was figured out that photochemical reactions may affect the $\mathrm{PM}_{2.5}$

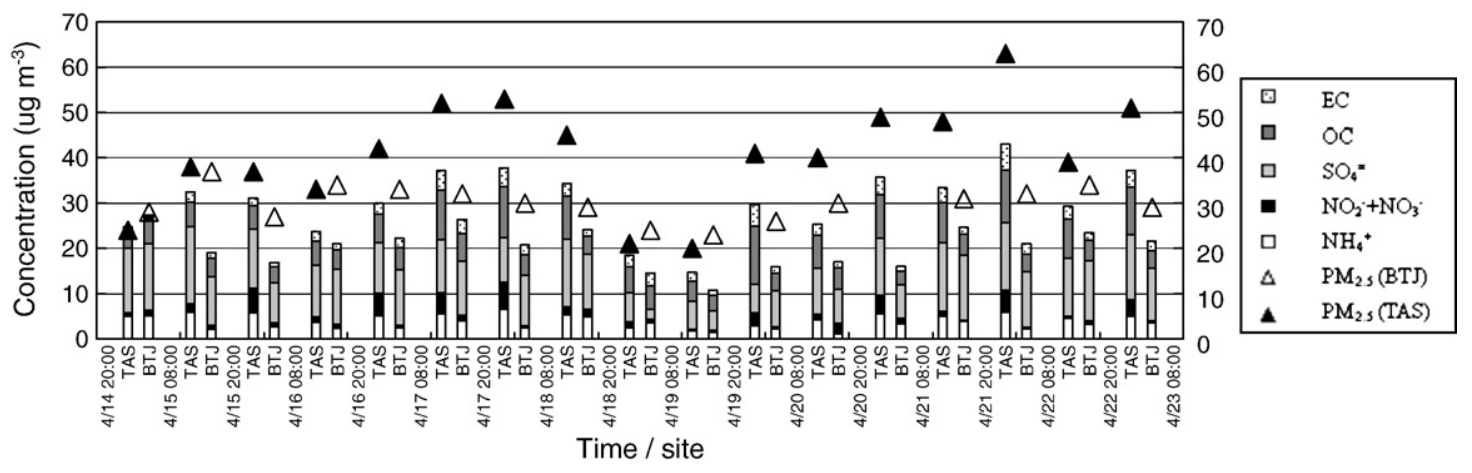

Fig. 10-12-hr averages of $\mathrm{PM}_{2.5}$ carbonaceous content and major water-soluble ions at the TAS (urban) and the BTJ (background) sites during intensive aerosol observation period. 
concentration. Lee and Hsu (1996) estimated the OC/EC concentration ratio from vehicle emissions to be 0.74 at the Jue-Chung tunnel in Taipei City. A similar value of 0.75 was obtained by Gillies et al. (2001). In this study, 0.74 was used to estimate secondary $\mathrm{PM}_{2.5}$ OC by the method of Turpin and Huntzicker (1995). As shown in Fig. 11, it is clear that $\mathrm{PM}_{2.5}$ OC, primary $\mathrm{PM}_{2.5} \mathrm{OC}$, and secondary $\mathrm{PM}_{2.5}$ OC variation trends were very similar at the TAS site. However, it was not the same at the BTJ site. On the average, the $\mathrm{PM}_{2.5}$ OC concentration at the TAS site was about twice that at the BTJ site. However, the calculation shows that secondary $\mathrm{PM}_{2.5}$ OC made up an average of about $36 \%$ of $\mathrm{PM}_{2.5}$ OC at the TAS site, which is lower by $72 \%$ for the BTJ site. It appears that primary $\mathrm{PM}_{2.5} \mathrm{OC}$ was made up mostly of $\mathrm{PM}_{2.5} \mathrm{OC}$, and the source of $\mathrm{PM}_{2.5} \mathrm{OC}$ at the BTJ site was also the source of $\mathrm{PM}_{2.5}$ at the TAS site. Relevantly, vehicles were the major sources of emissions in the Greater Taipei area. Moreover, from Table 4, the calculated organic matter (OM) made up about $20 \%$ of $\mathrm{PM}_{2.5}$ at the BTJ site.
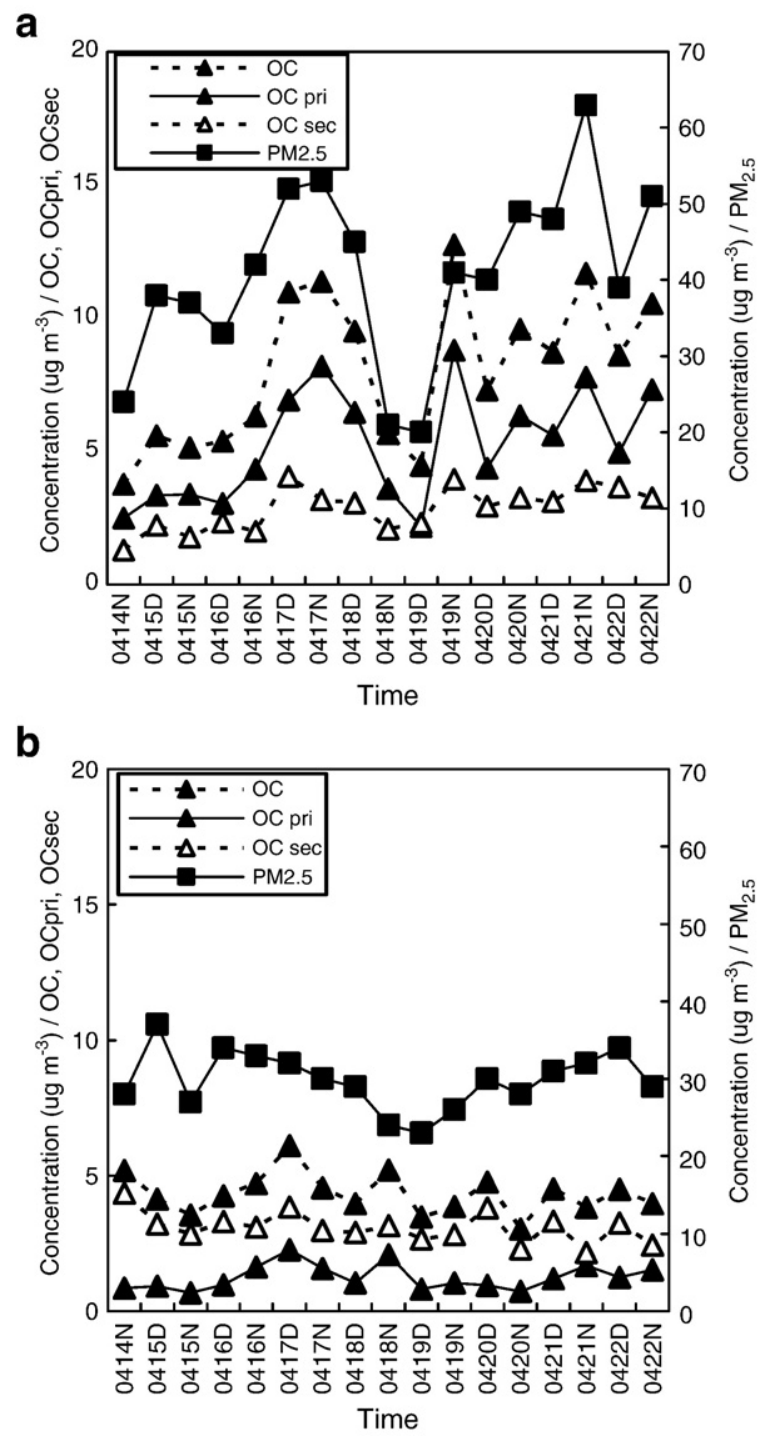

Fig. 11-12-hr averages of $\mathrm{PM}_{2.5}$ mass, organic carbon (OC), estimated primary $\mathrm{OC}$, and secondary $\mathrm{OC}$ concentrations during intensive aerosol observation period at (a) the TAS (urban) site, (b) the BTJ (background) site.
More research is therefore needed to find out whether OM is from LRT or photochemical reactions of volatile organic precursors emitted from the forests of SMC.

It is noted that HPPC, WHP, and WAF weather patterns had similar $\mathrm{PM}_{2.5}$ component distributions in the urban area as shown in Table 4. The difference between the event and the non-event periods was that the unresolved $\mathrm{PM}_{2.5}$ components made up $12.3 \%-16.5 \%$ of $\mathrm{PM}_{2.5}$ during the event periods, which were higher than $6.3 \%$ in the non-event period. This implies that there could be more minor $\mathrm{PM}_{2.5}$ components like particle-bound water or metals in the urban area. Relatively, at the BTJ site, aerosol chemical components varied much under different weather patterns, even though the average $\mathrm{PM}_{2.5}$ levels were similar during the observation period. This is probably due to the difference of trajectory paths for different weather patterns. From Figs. 5 and 6, the wind field observed at the PJY site (\#10 in Fig. 1), which was very near the BTJ background site, revealed the wind field at the BTJ site. Therefore, at the BTJ site, the HPPC weather pattern might have originated from the southeast ocean of Taiwan, while the WAF weather pattern might have come from the waters to the east or north of Taiwan, and the WHP weather pattern might have come from the waters to the southeast of Taiwan, since Therefore, it was not clear where the $\mathrm{PM}_{2.5}$ in air passing over the waters around Taiwan came from. However, from Table 4, it can be seen that $\mathrm{PM}_{2.5}$ nss-sulfate is the major component of $\mathrm{PM}_{2.5}$ at the BTJ site. It is thus concluded that during the observation period, the $\mathrm{PM}_{2.5}$ concentration at the BTJ site could be traced to the East Asian continent.

\section{Conclusions}

In this study, continuous $\mathrm{PM}_{2.5}$ data monitored at the Taipei aerosol supersite from March 2002 to February 2005, and the surface weather maps during the same time period are utilized to classify seven weather patterns for $\mathrm{PM}_{2.5}$ events. Among these weather patterns, HPPC, WAF, TYP, PHP, WHP, and WSW should be related to the influence of complex terrain. Especially, HPPC, WAF, and HPP prevailed in $77 \%$ of all the $\mathrm{PM}_{2.5}$ event days. Also, these three weather patterns prevailed in $46 \%$ of all the days from February to April. When $\mathrm{PM}_{2.5}$ level exceeded $65 \mu \mathrm{g} \mathrm{m}^{-3}$, the percentage of wind speed less than $1.5 \mathrm{~m} \mathrm{~s}^{-1}$ at the TPE site was over $60 \%$ under the HPPC and WAF weather patterns. The HPPC and WAF weather patterns occurred mainly in the winter, and the pollution was from LRT/LP. The $\mathrm{PM}_{2.5}$ event under HPP weather pattern was mainly from LRT. Based on the statistics, $15 \%$ of event days were contributed by LRT, $20 \%$ by LP, and $65 \%$ by LRT/LP. Less frequent $\mathrm{PM}_{2.5}$ event weather patterns such as TYP, WHP, PHP, and WSW appeared mainly in the summer and were mostly from LP. In the HPPC, WAF, and PHP weather patterns, the Taipei basin was located on the lee side of SMC under the southeast prevailing wind. The blocking effect of SMC plays an important role, which is the main cause of $\mathrm{PM}_{2.5}$ events occurring in the Taipei basin.

During the aerosol observation study, detailed evolution of the $\mathrm{PM}_{2.5}$ levels for the HPPC, WAF, and WHP weather patterns were determined. In the daytime, the sea breeze was important in determining the $\mathrm{PM}_{2.5}$ level. During nighttime, low wind 
speed during the hours after midnight was responsible for the $\mathrm{PM}_{2.5}$ accumulation under the HPPC and WAF weather patterns. Meanwhile, we also found that a shallow stable atmosphere caused $\mathrm{PM}_{2.5}$ events under the WHP and HPPC weather patterns. From the aerosol observations, it was also found that the $\mathrm{PM}_{2.5}$ $\mathrm{OM}$ and $\mathrm{PM}_{2.5}$ nitrate tended to accumulate in the Taipei basin during event days. This shows that local vehicle emissions are major sources in the formation of the $\mathrm{PM}_{2.5} \mathrm{OM}$ and $\mathrm{PM}_{2.5}$ nitrate in the Taipei basin. In contrast, on both events and non-event days, the fraction of $\mathrm{PM}_{2.5}$ sulfate in $\mathrm{PM}_{2.5}$ mass was high. It is thought that mainland China was the main source of $\mathrm{PM}_{2.5}$ sulfate observed in northern Taiwan.

In this study, we have evidenced that terrain blocking plays an important role in $\mathrm{PM}_{2.5}$ accumulation in the Taipei basin through historical monitoring data and an intensive aerosol observation. However, more detailed temporal and spatial investigations for each weather pattern are still needed to understand the precise $\mathrm{PM}_{2.5}$ formation mechanism.

\section{Acknowledgments}

We express our deep gratitude to the Taiwan National Science Council for providing financial support to this study (NSC 94-2111M-008-021-AGC). Likewise, we thank the Taiwan Environmental Protection Administration (TEPA) for providing monitoring data on the Taiwan aerosol supersite. Also, we acknowledge the Data Bank of Atmospheric Research (DBAR), managed by the Department of Atmospheric Sciences, National Taiwan University for sharing the atmospheric monitoring data used in this study.

\section{R E F E R E N C E S}

Abdalmogith SS, Harrison RM. The use of trajectory cluster analysis to examine the long-range transport of secondary inorganic aerosol in the UK. Atmos Environ 2005;39:6686-95.

Almbauer RA, Oettl D, Bacher M, Sturm PJ. Simulation of the air quality during a field study for the city of Graz. Atmos Environ 2000;34:4581-94.

ApSimon HM, Gonzalez del Campo MT, Adams HS. Modelling long-range transport of primiary particulate material over Europe. Atmos Environ 2001;35:343-52.

Archer CL, Jacobson MZ. The Santa Cruz eddy. Part II: mechanisms of formation. Mon Weather Rev 2005;133:2387-405.

Bachmeier AS, Newell RE, Shipham MC, Zhu Y, Blake DR, Browell EV. PEM-West A: meteorological overview. J Geophys Res 1996;101:1655-77.

Batalha JR, Saldiva PH, Clarke RW, Coull BA, Stearns RC, Lawrence $\mathrm{J}$. Concentrated ambient air particles induce vasoconstriction of small pulmonary arteries in rats. Environ Health Perspect 2002;110:1191-7.

Borge R, Lumbreras J, Vardoulakis S, Kassomenos P, Rodriguez E. Analysis of long-range transport influences on urban $\mathrm{PM}_{10}$ using two-stage atmospheric trajectory clusters. Atmos Environ 2007;41:4434-50.

Brighton BWM. Strongly stratified flow pass three-dimensional obstacles. Quart J Roy Met Soc 1977;104:189-307.

Chen ML, Mao IF, Lin IK. The PM and PM particles in urban areas of Taiwan. Sci Total Environ 1999;226:227-35.

Chen JL, Lee CT, Chang SY, Chou CCK. The elemental contents and fractal dimensions of $\mathrm{PM}_{2.5}$ in Taipei city. Aerosol Air Qual Res 2001;1:9-20.
Chen LY, Jeng FT, Chen CC, Hsiao TC. Hygroscopic behavior of atmospheric aerosol in Taipei. Atmos Environ 2003;37:2069-75.

Chen Y, Ludwig F, Street RL. Stably stratified flows near a notched transverse ridge across the Salt Lake valley. J Appl Meteorol 2004;43:1308-28.

Cheng WL. Synoptic weather patterns and their relationship to high ozone concentrations in the Taichung basin. Atmos Environ 2001;35:4971-94.

Chow JC, Watson JG, Pritchett LC, Pierson WR, Frazier CA, Purcell RG. The DRI thermal/optical reflectance carbon analysis system: description, evaluation and applications in U.S. Air Quality Studies. Atmos Environ 1993;27:1185-201.

Chung YS, Kim TK, Kim KH. Temporal variation and cause of acidic precipitation from a monitoring network in Korea. Atmos Environ 1996;30:2429-35.

Cousin F, Tulet P, Rosset R. Interaction between local and regional polluted layers in the low troposphere: impact on surface concentrations during ESCOMPTE 2001, IOP2. Atmos Res 2005;74:117-37.

Dayan U, Lamb D. Meteorological indicators of summer precipitation chemistry in central Pennsylvania. Atmos Environ 2003;37:1045-55.

Donaldson K, Li XY, Macnee W. Ultrafine (nanometre) particle mediated lung injury. J Aerosol Sci 1998;29:553-60.

Dorling SR, Davies TD. Extending cluster analysis-synoptic meteorology links to characterise chemical climates at six northwest European monitoring stations. Atmos Environ 1994;29:145-67.

Dosio A, Emeis S, Graziani G, Junkermann W, Levy A. Assessing the meteorological conditions of a deep Italian Alpine valley system by means of a measuring campaign and simulations with two models during a summer smog episode. Atmos Environ 2001;35:5441-54.

Gillies JA, Gertler AW, Sagebiel JC, Dippel WA. On-road $\mathrm{PM}_{2.5}$ and $\mathrm{PM}_{10}$ emissions in the Sepulveda Tunnel, Los Angeles California. Environ Sci Technol 2001;35:1054-63.

Harrison RM, Grenfell JL, Peak JD, Clemitshaw KC, Penkett SA, Cape $\mathrm{JN}$, et al. Influence of airmass back trajectory upon nitrogen compound composition. Atmos Environ 2000;34:1519-27.

Hsu SC, Liu SC, Jeng WL, Chou CCK, Hsu RT, Huang YT, et al. Lead isotope ratios in ambient aerosols from Taipei, Taiwan: Identifying long-range transport of airborne $\mathrm{Pb}$ from the Yangtze Delta. Atmos Environ 2006;40:5393-404.

Hung HF, Wang CS. Experimental determination of reactive oxygen species in Taipei aerosols. J Aerosol Sci 2001;32:1201-11.

Hunt JCR, Snyder WH. Experiments on stably and neutrally stratified flow over a model three-dimensional hill. J Fluid Mech 1980;96:671-704.

Jazcilevich AD, Garcia AR, Ruiz-Suarez LG. A study of air flow patterns affecting pollutant concentrations in the central region of Mexico. Atmos Environ 2003;37:183-93.

Jazcilevich AD, Garcia AR, Caetano E. Locally induced surface air confluence by complex terrain and its effect on air pollution in the valley of Mexico. Atmos Environ 2005;39:5481-9.

Jiang W, Hu F, Wang W. A non-hydrostatic dispersion modeling system and it's application to air-pollution assessments over coastal complex terrain. J Wind Eng Ind Aerodyn 2000;87:15-43.

Jordan CE, Dibb JE, Anderson BE, Fuelberg HE. Uptake of nitrate and sulfate on dust aerosols during TRACE-P. J Geophys Res 2003;108(D21):8817. doi:10.1029/2022JD003101.

Kassomenos P, Flocas HA, Lykoudis S, Skouloudis AN. Spatial and temporal characteristics of the relationship between air quality status and mesoscale atmospheric circulation over an urban Mediterranean basin. Sci Total Environ 1998;217:37-57.

Kassomenos P, Gryparis A, Samoli E, Katsouyanni K, Lykoudis S, Flocas HA. Atmospheric circulation types and daily mortality in Athens, Greece. Environ Health Perspect 2001;109:591-6. 
Kleeman MJ, Cass GR. Effect of emissions control strategies on the size and composition distribution of urban particulate air pollution. Environ Sci Technol 1999;33:177-89.

Lam KS, Wang TJ, Wu CL, Li YS. Study on an ozone episode in hot season in Hong Kong and transboundary air pollution over Pearl River Delta region of China. Atmos Environ 2005;39:1967-77.

Lee CT, Hsu WC. The source apportionment of urban aerosols from chemical properties of aerosol spectra near atmospheric sources. J Chin Inst Chem Eng 1996;19:1-13.

Lee CT, Chuang MT, Chan CC, Cheng TJ, Huang SL. Aerosol characteristics from the Taiwan aerosol supersite in the Asian yellow-dust periods of 2002. Atmos Environ 2006;40:3409-18.

Lin YL, Lin NH, Weglarz RP. Numerical modelling studied of lee mesolows, mesovortices and mesocyclones with application to the formation of Taiwan mesolow. Meteotol Atmos Phys 1992;49:43-67.

Lin CY, Liu SC, Chou CCK, Liu TH, Lee CT, Yuan CS, et al. Long-range transport of Asian dust and air pollutants to Taiwan. Terres Atmos Ocean Sci 2004;15:759-84.

Lin CY, Liu SC, Chou CCK, Huang SJ, Liu CM, Kuo CH, et al. Long-range transport of aerosols and their impact on the air quality of Taiwan. Atmos Environ 2005;39:6066-76.

Lu R, Turco RP. Air pollutant transport in a coastal environment - II three-dimensional simulations over Los Angeles basin. Atmos Environ 1995;29:1499-518.

Oberdörster G, Gelein RM, Ferin J, Weiss B. Association of particulate air pollution and acute mortality: involvement of ultrafine particles? Inhal Toxicol 1995;7:111-24.

Oberdörster G, Sharp Z, Attudorei V, Elder A, Gelein R, Lunts A. Extrapulmonary transiocation of ultrafine carbon particles following whole-body inhalation exposure of rats. J Toxicol Environ Health 2002;65:1531-43.

Oettl D, Almbauer RA, Sturm PJ, Piringer M, Baumann K. Analysing the nocturnal wind field in the city of Graz. Atmos Environ 2001;35:379-87.

Rainham DGC, Tomic KE, Sheridn SC, Burnett RT. Synoptic weather patterns and modification of the association between air pollution and human mortality. Int J Environ Health Res 2005;15:347-60.

Schmitz R. Modelling of air pollution dispersion in Santiago de Chile. Atmos Environ 2005;39:2035-47.

Seaton A, MacNee W, Donaldson K, Godden D. Particulate air pollution and acute health effects. Lancet 1995;345:176-8.
Sheridan SC. The redevelopment of a weather-type classification scheme for North America. Int J Climatol 2002;22:51-68.

Shimohara T, Oishi O, Utsunomiya A, Mukai H, Hatakeyama S, Sun-Eun J, et al. Characterization of atmospheric air pollutants at two sites in northern Kyushu, Japan - chemical form, and chemical reaction. Atmos Environ 2001;35:667-81.

Smith RB. The influence of mountains on the atmosphere. Adv Geophys 1979;21:87-230.

Smith RB. Linear theory of stratified hydrostatic flow past on isolated mountains. Tellus 1980;32:348-64.

Smolarkiewicz PK, Rotunno R. Low Froude number flow pass three-dimensional obstacles. Part 1: Baroclinically generated lee vortices. J Atmos Sci 1989;46:1154-64.

Smolarkiewicz PK, Rasmussee R, Clark TL. On the dynamics of Hawaiian cloud bands. J Atmos Sci 1988;45:1872-905.

Sun Q, Wexler AS. Modeling urban and regional aerosols near acid neutrality - applications to the 24-25 June SCAQS episode. Atmos Environ 1998;32:3533-45.

Sun WY, Chern JD, Wu CC, Hsu WR. Numerical simulation of mesoscale circulation in Taiwan and surrounding area. Mon Weather Rev 1991;119:2558-73.

TEPA. Environmental disbursement statistical survey report in 2004; 2004. EPA-93-M104-02-101, in Chinese.

TEPA. Environmental disbursement statistical survey report in 2005; 2005. EPA-94-M104-02-101, in Chinese.

Turnbull AB, Harrison RM. Major component contributions to $\mathrm{PM}_{10}$ composition in the UK atmosphere. Atmos Environ 2000;34:3129-37.

Turpin BJ, Huntzicker JJ. Identification of secondary organic aerosol concentrations during SCAQS. Atmos Environ 1995;29:3527-44.

Turpin BJ, Lim HJ. Species contributions to PM2.5 mass concetrations: revisiting common assumptions for estimating organic mass. Aerosol Sci Tech 2001;35:602-10.

Utell MJ. Inhalation of ultrafine particles alters blood leukocyte expression of adhesion molecules in humans. Environ Health Perspect 2006;114:51-8.

Venegas LE, Mazzeo NA. Atmospheric stagnation, recirculation and ventilation potential of several sites in Argentina. Atmos Res 1999;52:43-57.

Watson JG, Chow JC, Chen LWA. Summary of organic and elemental/ black carbon analysis methods and intercomparisons. Aerosol Air Qual Res 2005;5:69-109. 